Supplement of Clim. Past, 13, 855-878, 2017

https://doi.org/10.5194/cp-13-855-2017-supplement

(c) Author(s) 2017. This work is distributed under

the Creative Commons Attribution 3.0 License.

(c) (1)

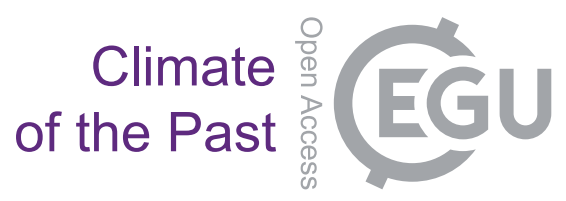

Supplement of

\title{
Water-mass evolution in the Cretaceous Western Interior Seaway of North America and equatorial Atlantic
}

James S. Eldrett et al.

Correspondence to: James S. Eldrett (james.eldrett@shell.com)

The copyright of individual parts of the supplement might differ from the CC BY 3.0 License. 


\section{SUPPLEMENTAL INFORMATION:}

\subsection{Study Sites}

\subsubsection{Shell Iona-1}

The upper part of the Eagle Ford Group (Gr.) and lowermost Austin Chalk crop out along Sycamore Creek about $18 \mathrm{~km}$ (11 miles) southeast of Del Rio near the Val Verde-Kinney County line, Texas (TX), USA. In January 2012 , Shell International Exploration and Production Inc. drilled the research core Iona-1 $\left(29^{\circ} 13.51^{\prime} \mathrm{N}, 100^{\circ} 44.49^{\prime} \mathrm{W}\right)$ approximately $600 \mathrm{~m}$ behind the Sycamore Creek bluff. From the surface, the core recovered the lower $40 \mathrm{~m}$ of the Austin Chalk, a 110 m long interval representing a nearly complete record of the Eagle Ford Gr. (Boquillas or Eagle Ford Formation, Fm.) and an upper part of the underlying Buda Limestone. A total of 180 meters of core were recovered spanning the lower Cenomanian to lower Coniacian (Eldrett et al. 2015). The underlying Buda Limestone and overlying Austin Chalk comprise extremely bioturbated limestones (ave. bed thickness $\sim 49 \mathrm{~cm}$ ) with thin marl beds (ave. thickness $\sim 9 \mathrm{~cm}$ ) and rare bentonites (ave. bed thickness $\sim 2 \mathrm{~cm}$ ), whereas the Eagle Ford Gr. is characterized by organic-rich marl beds (ave. thickness $\sim 72 \mathrm{~cm}$ ), thinner limestone beds (ave. thickness $\sim 9$ $\mathrm{cm}$ ) and numerous ( 270) thin-bedded, bentonite beds (ave. thickness $\sim 4 \mathrm{~cm}$, range $<1$ to $>60 \mathrm{~cm}$ ).

\subsubsection{Shell Innes-1}

Cenomanian to Turonian strata are also exposed in road cuts along US Highway 90, northwest of Del Rio near the town of Langtry in Terrell County, TX (Pessagno, 1969; Jiang et al. 1989; Donovan and Staerker, 2010; Donovan et al. 2012; Lowery et al. 2014), approximately $160 \mathrm{~km}$ (100 miles) WNW of the Iona-1 core, and $50 \mathrm{~km}$ (35 miles) east of the Lozier Canyon outcrop. Shell International Exploration and Production Inc. drilled the research core Innes-1 $\left(29^{\circ} 49.51^{\prime} \mathrm{N}, 101^{\circ} 37.34^{\prime} \mathrm{W}\right)$ immediately behind one of these exposures recovering the lower $20 \mathrm{~m}$ of the Austin Chalk, over 60m of the Eagle Ford Gr. (Boquillas Fm.) and underlying Buda Limestone.

\subsubsection{Well ' $X$ '}

Samples were also analysed from sedimentary rocks spanning part of the Eagle Ford Gr., that were recovered from the subsurface well ' $X$ ' core, located in the central part of the Maverick Basin, TX (Main text Fig. 1).

\subsubsection{Bouldin Creek outcrop section}


In addition to the detailed core analyses, an outcrop investigation of the Eagle Ford Gr. was conducted for comparison purposes along Bouldin Creek located parallel to the Missouri-Pacific railroad line and adjacent to the Daugherty Arts Center on Barton Spring Road in Austin, TX. The Eagle Ford Gr. exposures along the creek are locally assigned to the Pepper Shale, Cloice Shale and the Bouldin Flags Members, and the South Bosque Shale Fm. (Stenzel, 1953; Pessagno, 1969). The Pepper Shale Member (Mb.) of the Lake Waco Fm. in outcrop is a recessive, dark gray, argillaceous mudstone. It was originally defined along Bouldin Creek by Young (1977). Currently it is relatively thin $(\sim 14 \mathrm{~m}$ thick; see Minisini et al. in review) and only partly exposed in outcrop, no samples were analysed for palynology. The Cloice Mb. is also only partly exposed and consists of argillaceous mudstones. The Bouldin Flags Mb. as measured at Bouldin Creek is approximately $4 \mathrm{~m}$ thick, comprising dark gray to black mudstones, bentonites (up to $15 \mathrm{~cm}$ thick) and interbedded limestones $(\sim 10-30 \mathrm{~cm}$ thick) that may be massive or cross bedded and may locally contain bivalve or oyster lags and large pieces of carbonized wood. The South Bosque Fm. is a homogenous, approximately $5 \mathrm{~m}$ thick deposit of calcareous marl with interbedded thin bentonites (less than $3 \mathrm{~cm}$ thick). Age assignments are based on this study and supplemented by previous foraminiferal, nannofossil and isotope analyses (Pessagno, 1969; Lundquist, 2000; Jiang, 1989; Lowery et al. 2014). Palynological samples come from a $10.7 \mathrm{~m}$ interval of a $22 \mathrm{~m}$ exposed creek section.

\subsubsection{USGS Portland-1}

Sedimentary rocks were also analysed for comparison from the USGS Portland-1 core $\left(38^{\circ} 22.36^{`} \mathrm{~N}, 105^{\circ} 01.18^{\prime}\right.$ W) located in the central Cretaceous Western Interior Seaway (KWIS), near the base Turonian GSSP section (Kennedy et al. 2000, 2005) at Pueblo (Colorado, USA). The new data cover the Cenomanian equivalent interval spanning from oldest to youngest: the Dakota Sandstone, Graneros Shale, Lincoln Limestone, Harland Shale and lowermost part of the Bridge Creek Limestone. The new $\delta^{13} \mathrm{C}_{\mathrm{org}}$ isotope data collected was integrated with existing $\delta^{13} \mathrm{C}_{\text {org }}$ data from this core (Sageman et al. 2006; Duvivier et al. 2014; Joo and Sageman, 2014).

\subsubsection{ODP Leg 207, Sites 1260 and 1261; Demerara Rise}

In order to understand the characteristics of a tethyan water-mass; samples were also analysed from Site 1261 (Hole A: $9^{\circ} 2.917^{\prime} \mathrm{N}, 54^{\circ} 19.038^{\prime} \mathrm{W}$; Hole B: $9^{\circ} 2.918^{\prime} \mathrm{N}, 54^{\circ} 19.049^{\prime} \mathrm{W}$ ) and 1260 (9 $\left.15.931^{\prime} \mathrm{N}, 54^{\circ} 32.652^{\prime} \mathrm{W}\right)$; both recovered during ODP Leg 270 to the Demerara Rise, offshore Suriname in the tropical Atlantic. Cenomanian to lower Turonian sediments on Demerara Rise are mainly expressed by distinctly laminated black shales with interbedded light-colored, laminated foraminiferal packstones and wackestones (Shipboard Scientific Party, 
2004a, 2004b). Detailed isotope stratigraphy provided by Erbacher et al. (2005); and supplemented by Meyers (2007); Forster et al. (2007) and Friedrich et al. (2008) was utilized in this study enabling isotope correlation between ODP Sites 260 and 1261 with those sections in the KWIS.

\subsubsection{ODP Leg 183, Site 1138, Kerguelen Plateau}

Palynological analyses was also conducted on eight sedimentary samples recovered from the part of the Cenomanian-Turonian sections (655-660m) from ODP Site 1138 (53³3.1047’ S; 75 58.4926’ E), Kerguelen Plateau. The Cenomanian-Turonian sediments comprise organic rich claystones and inter-bedded nannofossil claystone and Chalk, overlying a glauconite bearing calcareous sandstone unit (Shipboard Scientific Party, 2000). The age model is based on integrated carbon isotope and bio-stratigraphy as presented in Dickson et al. (2016) and combined with previously published geochemical analyses (see Dickson et al. 2016).

\subsection{Methods}

\subsubsection{Palynological methods}

Sample splits were sequentially dissolved in hydrochloric $(30 \% \mathrm{HCl})$ and hydrofluoric $(60 \% \mathrm{HF})$ acids. Post-HF oxidative treatment was necessary to liberate palynomorphs from the prominent translucent, fluffy amorphous organic matter (AOM). Subsequent treatment with an alkali solution was necessary to remove post-oxidation waste products. Previous work on Cenomanian - Turonian organic-rich shales has indicated that excessive post-HF treatment led to selective destruction of gonyaulacacean and areoligeracean dinocysts (Dodsworth, 1995, 1996, 2004). Experiments with Eagle Ford post-HF residues indicated that "optimum oxidation" was achieved with extended maceration in cold nitric acid (HNO3). Samples containing prominent AOM were further subjected to maceration in warm $\mathrm{HNO} 3$ (heated to $\left.50^{\circ} \mathrm{C}\right)$ and treated with Schulze's Solution $(70 \%$ nitric acid supersaturated with potassium chlorate and/or fuming nitric acid), followed by a single rinse in a detergent that contained a trace of ammonia. This produces fairly uniform fossil assemblages with greatly reduced AOM concentrations, although scanning over many remaining AOM fragments was necessary to achieve sufficient specimen counts. Single Lycopodium tablets were added to samples after laboratory oxidation for absolute quantification of palynomorphs (counts per gramme; Mertens et al. 2009). Previous experiments have shown that the oxidation required to liberate palynomorphs from AOM destroys a large proportion of Lycopodium spores if they are added prior to oxidation. Lund University, Batch No. 1031 (2011) tablets were used. Each tablet contains 20,848 Lycopodium spores ( \pm 
are underestimates. However, values obtained are of the same order as the only previously published KWIS study of the Cenomanian - Turonian palynomorph concentration (Dodsworth, 2000), i.e. values generally between 100 and 8000 specimens per gram. Due to the relative low recovery of palynomorphs from ODP Sites 1260 and 1261 ; Lycopodium spikes were not added preventing absolute abundance counting.

The ratio between terrestrial $(\mathrm{T})$ and marine $(\mathrm{M})$ palynomorphs (T:M ratio) was used as a proxy for terrestrial input. Dinocyst based reconstruction of marine productivity is primarily based on the ratio of (proto-) peridinioid (P) versus gonyaulacoid $(\mathrm{G})$ cysts of dinocyst assemblages with P-cysts associated with high nutrient input, dominating regions of upwelling, restricted marine or nearshore regions with high terrestrial nutrient input, or regions of sea-ice being associated with a heterotrophic lifestyle and feeding strategy (see review and references in Sluijs et al. 2005). Conversely, G-cysts are considered autotrophic inhabiting more oligotrophic and open marine environments (Sluijs et al. 2005). However, it has been recognized that not all living P-cysts are heterotrophic (Dale and Fjellså, 1994; Sluijs et al. 2005) and therefore doubt has been raised over the autecological affinity (heterotrophic or autotrophic) of fossil cysts and the use of the $\mathrm{P} / \mathrm{G}$ cyst ratio in general for paleo-productivity reconstructions. Nevertheless, whereas the unknown autecological affinity of fossil dinocysts may complicate the interpretation of the $\mathrm{P} / \mathrm{G}$ ratio, it has been shown that despite the inevitable inclusion of $\mathrm{P}$-cysts with autotrophic feeding strategy in such a ratio, the paleoenvironmental signal has not been obscured (see Sluijs et al. 2005). Despite these drawbacks, the $\mathrm{P} / \mathrm{G}$ cyst ratio has been applied to Cretaceous strata with the results being corroborated by other sedimentological, biological and geochemical proxy data (e.g., Pearce et al. 2009; Prauss, 2012a, 2012b; van Helmond et al. 2014). However, the interpretation of the P/G dinocyst ratio may also be impacted by differential preservation of dinocysts due to bottom-water and pore water redox conditions. In Quaternary sediments, oxidation of organic matter has been shown to result in degradation and preferential removal of P-cysts from palynological assemblages (Reichart and Brinkhuis, 2003; Zonneveld et al. 2007). The opposite seems to have been the case in mid-Cretaceous strata from the KWIS, where Dodsworth $(1995,2000)$ demonstrated the preferential destruction and removal of G-cysts from the palynological assemblage. In unpublished experiments by P.D. on Paleocene and Eocene rocks it has been noted that some protoperidinioid Pcysts, a group that do not extend back to mid-Cretaceous times, are significantly less oxidation resilient than other types of P-cyst, including longer-ranging genera such as Subtilisphaera. In any case, it has generally been recognized that caution should be exercised in interpreting relative abundances and the ratio between P- and Gcysts, whereas the absolute abundance concentration of P- and G-cysts should more accurately reflect sea surface 
productivity conditions (see Reichart and Brinkhuis, 2003). We therefore calculated the ratio of P:G dinocyst individuals, and absolute abundances as proxies for organic paleoproductivity and to asses organic matter oxidation potential.

Separate kerogen and post-oxidation biostratigraphy slides were prepared. All preparations were sieved at $15 \mu \mathrm{m}$. The palynological counting technique used in this study involved making an initial count of 100 palynomorphs to estimate percentages of peridinioid, areoligeracean, ceratioid, dinogymnioidean and gonyaulacacean dinocysts, prasinophyte algae, acanthomorph and sphaeromorph acritarchs, foraminiferal test linings and terrigenous and fresh- / brackish-water palynomorphs. Counting of dinocysts was continued until a total of approximately 100 specimens were reached. Remaining slide material was thoroughly scanned for additional rare palynomorph taxa. Relative abundances are described as rare (<1-2), frequent (3-9), common (10-24), abundant (25-49) or superabundant (50+). Full dinocyst names with authors can be found in Fensome and Williams (2004).

\subsubsection{Geochemical methods}

Samples were analysed for major elements and trace metals using Inductively-Coupled Plasma Mass Spectroscopy (ICP MS) and Optical Emission Spectroscopy (OES) at Chemostrat Ltd, UK. To evaluate the redox state, we determined the concentrations of redox sensitive trace metals (TMs), in particular, Molybdenum (Mo), Uranium (U), Vanadium (V) and Zinc (Zn), all of which have been widely used to infer paleo-redox conditions in modern and ancient sediments (Brumsack, 2006; Tribovillard et al. 2006; Algeo et al. 2012). These redox-sensitive TMs show variable solubility with redox state, resulting in authigenic enrichments in oxygen-depleted sedimentary environments. We calculated TM enrichment factors (TMEF) normalized to Zirconium (Zr) and average shale (Brumsack, 2006). Relevant trace metal elements and major oxides were also cross-correlated with Aluminium to determine detrital contributions and presented in Eldrett et al.., (2015b). All elemental data and associated measurement accuracy are provided in the supplementary datafile.

Bulk organic carbon isotope analyses were also conducted on the organic fraction $\left(\delta^{13} \mathrm{C}_{\text {org }}\right)$. An aliquot of each powdered sample was reacted with $\sim 50 \mathrm{mls}$ of $10 \% \mathrm{HCl}$ overnight to remove any carbonate present, the acid was decanted, and then the sample was rinsed 3-4 times with $250 \mathrm{ml}$ of de-ionized water. The samples were dried in a $60^{\circ} \mathrm{C}$ oven and analyzed using a MAT253 mass spectrometer at the Dept. of Earth Sciences Isotope Labs, 
Southern Methodist University, Dallas, TX. Isotopic values are reported relative to Pee Dee Belemnite (PDB); analytical uncertainties based on replicate and standard analyses are $<0.1 \%$. Carbonate and organic $\mathrm{C}$ concentrations were determined during the stable isotope analysis workflow. Total Organic Carbon (TOC) analyses were also performed on selected samples using a Leco C230 analyzer. Analytical uncertainties for both methods are $<0.1 \mathrm{wt} \%$.

\subsection{Age models}

The age models for the studied sections are based on integrated biostratigraphy (palynology, foraminifera, nannofossils) and carbon isotopes combined with $\mathrm{U}-\mathrm{Pb}$ dating of individual zircons from bentonites layers in both Iona and Innes cores (see Eldrett et al., 2015a, Minisini et al. in review) and astronomically calibrated (Eldrett et al. 2015a). Of note for this contribution is that the shape and amplitude of the Cenomanian-Turonian Oceanic Anoxic Event 2 carbon isotope excursion (C-T OAE-2 CIE) in all three TX cores is similar to other records in the KWIS (e.g. Bowman and Bralower, 2005; Sageman et al. 2006; Joo and Sageman, 2014) with the intra CIE peaks as identified by Pratt and Threlkeld (1984) being clearly resolved (main text Fig. 3). However, compared to the

KWIS reference section (Joo and Sageman, 2014) our $\delta^{13}$ Corg isotopic record shows several precursor isotope excursions of approximately $\sim 1.5 \%$ in Iona-1 between 111.36 and $107.17 \mathrm{~m}$, which immediately precede and ultimately build up to the C-T CIE. In Portland- 1 core, two isotope shifts in the order of $\sim 1 \%$ are recorded (Duvivier et al. 2014) but are not included in the KWIS reference curve of Joo and Sageman (2014). These precursor shifts in Portland-1 may correspond to the precursor events in Iona-1, with the third and youngest missing in an unconformity at the base of the Bridge Creek Limestone ('bone bed'). Similarly, in both Innes-1 and well ' $\mathrm{X}$ '; some of these precursor events are missing, which combined with sedimentological evidence such as firmgrounds (i.e. 53m in Innes-1; see detailed discussion in Minisini et al. in review) indicate a hiatus at the base of the Cenomanian-Turonian CIE at these sites. Subsequently to Eldrett et al. (2014), the authors now believe that the onset of OAE-2 occurs at the first possible rise of the stable carbon isotope curve (112.45 $\mathrm{m}$ in Iona-1) including the precursor events and occurring below the Last Occurrence (LO) of the planktonic foraminiferan Thalmanninella greenhornensis as also reported in Europe (Jarvis et al. 2011). Therefore, the duration of the OAE2 interval is substantially longer $(0.92 \pm 0.17$ Myrs) than other KWIS records and that previously reported from European sections ( 0.45 Myrs; Voigt et al., 2008) and supports that these other sections are incomplete due to hiatal/omission surface at the base of the recorded CIE and indicates an earlier initiation of the OAE-2 than previously recognized (Eldrett et al. 2015). 


\subsection{Palynological results}

\subsubsection{Biostratigraphy}

The Dakota Sandstone in the Portland-1 core is the oldest sedimentary unit in the present study. It contains longranging terrigenous palynomorphs in the lower part, $211.61 \mathrm{~m}$ to $211.53 \mathrm{~m}$, and dinocyst taxa indicative of proximity to the Albian - Cenomanian boundary in the upper part, including Ovoidinium scabrosum and Senoniasphaera microreticulata, which have a (possibly reworked) range top just above the unconformity at the base of the overlying Graneros Shale at $204.39 \mathrm{~m}$, The lower part of the Graneros Shale, up to the Thatcher Limestone, contains dinocyst taxa including rare Ovoidinium verrucosum, and frequent Xiphophoridium alatum and Kiokansium unituberculatum from $184.53 \mathrm{~m}$, consistent with an early Cenomanian age and correlation with the Buda Fm. in Texas.

The biostratigraphy of the Eagle Ford Gr., including that of organic-walled phytoplankton, is discussed in detail by Eldrett et al. (2015) and Dodsworth (2016) for Iona-1 and Lozier Canyon. As indicated in Table S1, the dinocyst and prasinophyte bioevents discussed in the publications can be correlated with those in the other Eagle Ford Gr. sections documented in the present paper, and with the Portland-1 core and Pueblo outcrop in Colorado.

Most of the KWIS correlative bioevents are not recognised in the low diversity dinocyst assemblages at Demerara Rise ODP Sites 1260 and 1261. Arai et al. (2000) also reported relatively low diversity Cenomanian and Turonian dinocyst assemblages from marine deposits along the Brazilian margin of the proto-Atlantic and ascribed the low diversity to oceanic anoxia. The intra-upper Cenomanian cosmopolitan dinocyst marker events, top consistent and top common Litosphaeridium siphoniphorum are however present in Site 1260, at 426.87m and 427.84m (MCD) respectively; a short distance (i.e. the first samples analysed) below the OAE-2 CIE (main text Fig. 9). As noted in Section 1.4.2, a sharp decline in prasinophyte phycomata recorded in the KWIS below the OAE-2 interval (top of Influx 2 in Table S1) occurs at both Demerara Rise sites.

At Kerguelen Plateau Site 1138, top consistent / frequent Litosphaeridium siphoniphorum (> 3 specimens per coverslip in this section) is recorded at $657.07 \mathrm{~m}$, a short distance (i.e. the first sample analysed) below the OAE2 CIE. It is noteworthy that this is coincident with the range top of the dinocyst Hapsocysta peridictya, as also recorded in other high latitude southern hemisphere sections in New Zealand (Hasegawa et al. 2013; Schiøler \& 
Crampton, 2014). Cyclonephelium compactum-membraniphorum is present throughout the sampled section, including the basal sandstone at $659.80 \mathrm{~m}$. Its range base is used as a late Cenomanian age indicator in mid-latitudes but it has an older stratigraphic range base at high palaeo-latitudes (Eldrett et al. 2014; van Helmond et al. 2016). Its lowest common occurrence in the first sample analysed above top consistent / frequent L. siphoniphorum 5 correlates with that in the northern hemisphere (e.g. Table S1 and Dodsworth, 2000; Fig. 12). The dinocyst Adnatosphaeridium tutulosum has an uppermost Cenomanian range top in the northern hemisphere (e.g. Marshall \& Batten, 1988; Jarvis et al. 2011; Table S1). Its detailed range has not previously been published from the southern hemisphere. Its presence at Site 1138A from the shallowest sample analysed here, $655.10 \mathrm{~m}$, is above the OAE-2 CIE and the range bases of Turonian calcareous nannofossil marker taxa Quadrum gartneri (655.75m) and Eprolithus eptapetalus (655.70m) (Dickson et al. 2016), indicating it ranges into the lower Turonian in this region. 


\begin{tabular}{|c|c|c|c|c|c|c|c|c|c|c|c|c|}
\hline Chronostrat. & $\begin{array}{l}\text { Lithostrat. } \\
\text { TX }\end{array}$ & \multicolumn{2}{|c|}{$\begin{array}{r}\text { Eldrett et al. } 2015 \\
\text { bio-event \& age }\end{array}$} & $\begin{array}{l}\text { Phytoplankton marker taxa / events } \\
\text { Key: I- Common: A Abundant; Core depth or outcrop height above Buda }\end{array}$ & $\begin{array}{l}\text { IONA-1 } \\
\text { core, TX }\end{array}$ & $\begin{array}{l}\text { INNES-1 } \\
\text { core, TX }\end{array}$ & $\begin{array}{l}\text { Well } \mathrm{X} \\
\text { core, } \mathrm{TX}\end{array}$ & $\begin{array}{c}\mathrm{AU}-2 \\
\text { outcrop, } \mathrm{TX}\end{array}$ & $\begin{array}{l}\text { Lozier Cany. } \\
\text { outcrop, TX }\end{array}$ & $\begin{array}{l}\text { Portland-1 } \\
\text { core, Co }\end{array}$ & $\begin{array}{l}\text { Pueblo outcrop, } \\
\text { CO, G.S.S.P. }\end{array}$ & $\begin{array}{l}\text { Lithostrat. } \\
\text { co }\end{array}$ \\
\hline & \multirow[b]{2}{*}{ Austin Chalk } & \multirow{2}{*}{$\begin{array}{l}\text { Age in lona-1 } \\
89.45 \mathrm{Ma} \\
90.17 \mathrm{Ma}\end{array}$} & \multirow[b]{2}{*}{$\begin{array}{l}\text { Event P14 } \\
\text { Event P13 }\end{array}$} & \multirow{3}{*}{$\begin{array}{l}\text { LO Senoniasphaera rotundata I } \\
\text { LO Isabelidinium magnum } \\
\text { FO Senoniasphaera rotundata I } \\
\text { LO Prasinophyte phycomata } \\
\text { FO Prasinophyte phycomata }\end{array}$} & & & & & & & & \\
\hline $\begin{array}{c}\text { lower } \\
\text { Coniacian }\end{array}$ & & & & & $\begin{array}{l}7.91 \mathrm{~m} \\
7.91 \mathrm{~m} \\
37.89 \mathrm{~m}\end{array}$ & $\begin{array}{l}12.26 \mathrm{~m}^{*} \\
17.45 \mathrm{~m} \\
22.50 \mathrm{~m}\end{array}$ & \multirow{3}{*}{$\begin{array}{l}\text { Not } \\
\text { cored }\end{array}$} & $\begin{array}{l}\text { Notod } \\
\text { sampled } \\
19.50 \mathrm{~m}\end{array}$ & $\begin{array}{c}57.15 \mathrm{~m}^{*} \\
44.81 \mathrm{~m}(\mathrm{low})\end{array}$ & & \multirow[t]{2}{*}{$\begin{array}{l}\text { Not } \\
\text { sampled }\end{array}$} & $\begin{array}{l}\text { Niobrara Fm, } \\
\text { Fort Hays Lst } \\
\text { Member }\end{array}$ \\
\hline $\begin{array}{l}\text { upper } \\
\text { Turonian }\end{array}$ & \multirow{4}{*}{$\begin{array}{l}\text { Upper } \\
\text { Eagle } \\
\text { Ford }\end{array}$} & & & & $\begin{array}{l}42.53 \mathrm{~m} \\
52.57 \mathrm{~m} \\
52.57 \mathrm{~m}\end{array}$ & $\begin{array}{l}26.73 \mathrm{~m} \\
33.30 \mathrm{~m} \\
34.60 \mathrm{~m}\end{array}$ & & $\begin{array}{l}19.70 \mathrm{~m}^{*} \\
19.50 \mathrm{~m}\end{array}$ & $45.42 \mathrm{~m}$ & & & $\begin{array}{l}\text { Carlile Shale } \\
\text { Formation }\end{array}$ \\
\hline $\begin{array}{l}\text { middle } \\
\text { Turonian }\end{array}$ & & $\begin{array}{l}91.94 \mathrm{Ma} \\
92.28 \mathrm{Ma} \\
92.87 \mathrm{Ma}\end{array}$ & \begin{tabular}{|l} 
Event P12 \\
Event P11 \\
Event P10
\end{tabular} & $\begin{array}{l}\text { FO Senoniasphaera turonica } \\
\text { FO Senoniasphaera turonica Consistent } \\
\text { FO Heterosphaeridium difficile (rare, sporadic) } \\
\text { LO Cyclonephelium compactum-membraniphorum } \\
\text { Base of middle Turonian substage at Pueblo }\end{array}$ & $\begin{array}{l}58.74 \mathrm{~m} \\
60.93 \mathrm{~m} \\
65.12 \mathrm{~m} \\
72.77 \mathrm{~m}\end{array}$ & $\begin{array}{l}41.78 \mathrm{~m} \\
42.84 \mathrm{~m} \\
41.78 \mathrm{~m} \\
44.62 \mathrm{~m}\end{array}$ & & $13.70 \mathrm{~m}$ & $42.52 \mathrm{~m}$ & sampled & $\begin{array}{c}\text { Bed } 116 \text { (M.n.) (low) } \\
\text { Bed } 113 \text { (M.n.) (low) } \\
\text { Bed } 95 \text { (W.C.) (low) } \\
\text { Bed } 120 \text { (C.w.) } \\
\text { (base of Bed 120) }\end{array}$ & $\begin{array}{l}\text { Middle } \\
\text { Bridge Creek } \\
\text { Limestone }\end{array}$ \\
\hline $\begin{array}{l}\text { lower } \\
\text { Turonian }\end{array}$ & & $\begin{array}{l}92.95 \mathrm{Ma} \\
93.76 \mathrm{Ma}\end{array}$ & $\begin{array}{l}\text { Event P9 } \\
\text { Event P8 }\end{array}$ & $\begin{array}{l}\text { FO Eurydinium glomeratum I } \\
\text { FO Chatangiella spectabilis / spp. (rare, sporadic) } \\
\text { FO Eurydinium glomeratum } \\
\text { Base of Turonian Stage / lower Turonian substage }\end{array}$ & $\begin{array}{l}74.50 \mathrm{~m} \\
87.88 \mathrm{~m}\end{array}$ & $43.42 \mathrm{~m}$ & & $13.70 \mathrm{~m}$ & $39.93 \mathrm{~m}$ & $(143.80 \mathrm{~m})$ & \begin{tabular}{|c|} 
Bed 112 (M.n.) \\
Bed 109 (M.n.) \\
Bed 102 (M.n.) \\
(base of Bed 86) \\
\end{tabular} & Member \\
\hline \multirow[t]{2}{*}{$\begin{array}{c}\text { upper } \\
\text { Cenomanian }\end{array}$} & & $\begin{array}{l}93.81 \mathrm{Ma} \\
94.56 \mathrm{Ma} \\
94.59 \mathrm{Ma}\end{array}$ & $\begin{array}{l}\text { Event P7 } \\
\text { Event P6 } \\
\text { Event P5 }\end{array}$ & $\begin{array}{l}\text { LO Adnatosphaeridium ? chonetum } \\
\text { FO Cyclonephelium compactum-membraniphorum I } \\
\text { LO Litosphaeridium siphoniphorum Consistent } \\
\text { LO Adnatosphaeridium tutulosum Consistent } \\
\text { LO Wuroia spp. I Diplofusa gearlensis I } \\
\text { LO Litosphaeridium siphoniphorum I } \\
\text { FO Cyclonephelium comp.-membraniph. Consistent }\end{array}$ & {$\left[\begin{array}{c}88.77 \mathrm{~m} \\
102.95 \mathrm{~m} \\
103.44 \mathrm{~m} \\
104.18 \mathrm{~m} \text { (low) } \\
104.18 \mathrm{~m} \\
104.83 \mathrm{~m} \\
105.96 \mathrm{~m}\end{array}\right.$} & $\begin{array}{l}48.10 \mathrm{~m} \\
49.81 \mathrm{~m} \\
51.08 \mathrm{~m} \\
50.50 \mathrm{~m} \\
51.08 \mathrm{~m} \\
51.08 \mathrm{~m} \\
.52 .13 \mathrm{~m} \\
\end{array}$ & $\begin{array}{l}1630.47 \mathrm{~m} \\
1630.47 \mathrm{~m} \\
1630.47 \mathrm{~m} \\
1626.26 \mathrm{~m} \\
1630.47 \mathrm{~m} \\
1631.11 \mathrm{~m} \\
1632.17 \mathrm{~m}\end{array}$ & $\begin{array}{c}\text { Stratigraphic } \\
\text { Break }\end{array}$ & $\begin{array}{l}32.31 \mathrm{~m} \\
29.66 \mathrm{~m} \\
33.53 \mathrm{~m} \\
29.66 \mathrm{~m} \\
28.96 \mathrm{~m} \\
28.62 \mathrm{~m}\end{array}$ & \begin{tabular}{|l|}
$146.18 \mathrm{~m}$ \\
$146.53 \mathrm{~m}$ \\
$146.94 \mathrm{~m}$ \\
$146.18 \mathrm{~m}$ \\
$146.94 \mathrm{~m}$ \\
\\
$147.22 \mathrm{~m}$ \\
\end{tabular} & \begin{tabular}{|c|} 
upper Bed $78($ N.j.) \\
Bed 74 (S.g.) \\
Bed 73 (S.g.) \\
upper Bed 78 (N.j.) \\
Bed $73($ S.g.) \\
Bed 73 (S.g.) \\
Bed 63 (S.g.) \\
\end{tabular} & $\begin{array}{l}\text { Lower } \\
\text { Bridge Creek } \\
\text { Limestone } \\
\text { Member }\end{array}$ \\
\hline & \multirow{3}{*}{$\begin{array}{l}\text { Lower } \\
\text { Eagle } \\
\text { Ford }\end{array}$} & & & $\begin{array}{l}\text { LO Bosedinia cf. sp. } 1 \text { \& } 3 \text { I } \\
\text { FO Gonyaulacoid dinocysts } \\
\text { LO Prasinophyte phycomata (Influx 2) } \\
\text { FO Isabelidinium magnum Consistent } \\
\text { FO Foraminiferal test linings Consistent } \\
\text { LO Crassosphayera spp. } \\
\text { FO Prasinophyte phycomata } \\
\text { (Influx 2) }\end{array}$ & $\begin{array}{l}106.45 \mathrm{~m} \\
107.82 \mathrm{~m} \\
108.77 \mathrm{~m} \\
108.77 \mathrm{~m} \\
114.04 \mathrm{~m} \\
118.16 \mathrm{~m} \\
118.16 \mathrm{~m}\end{array}$ & $\begin{array}{l}53.33 \mathrm{~m} \\
53.65 \mathrm{~m} \\
53.98 \mathrm{~m} \\
52.43 \mathrm{~m} \\
53.98 \mathrm{~m} \\
57.98 \mathrm{~m} \\
58.80 \mathrm{~m}\end{array}$ & $\begin{array}{l}1636.40 \mathrm{~m} \\
1638.57 \mathrm{~m} \\
1638.57 \mathrm{~m} \\
\\
1637.87 \mathrm{~m} \\
1647.26 \mathrm{~m} \\
1647.83 \mathrm{~m}\end{array}$ & $\begin{array}{c}\text { Stratigraphic } \\
\text { Break }\end{array}$ & $\begin{array}{l}28.50 \mathrm{~m} \\
26.52 \mathrm{~m}\end{array}$ & $\begin{array}{c}154.18 \mathrm{~m}(\mathrm{low}) \\
147.90 \mathrm{~m} \\
150.82 \mathrm{~m} \\
154.18 \mathrm{~m} \\
\\
155.45 \mathrm{~m}\end{array}$ & $\begin{array}{l}\text { Not } \\
\text { sampled }\end{array}$ & $\begin{array}{l}\text { Hartland Shale } \\
\text { Member }\end{array}$ \\
\hline \multirow{2}{*}{$\begin{array}{c}\text { middle } \\
\text { Cenomanian }\end{array}$} & & $\begin{array}{l}95.36 \mathrm{Ma} \\
95.41 \mathrm{Ma}\end{array}$ & $\begin{array}{l}\text { Event P3 } \\
\text { Event P2 }\end{array}$ & $\begin{array}{l}\text { LO Circulodinium longispinatum I / Consistent } \\
\text { LO Bosedinia cf. sp. } 1 \text { \& } 3 \\
\text { FO Bosedinia cf. sp. } 1 \text { \& } 3\end{array}$ & $\begin{array}{l}119.49 \mathrm{~m} \\
119.77 \mathrm{~m} \\
132.76 \mathrm{~m}\end{array}$ & $\begin{array}{l}58.80 \mathrm{~m} \\
60.58 \mathrm{~m} \\
69.27 \mathrm{~m}\end{array}$ & $\begin{array}{l}1650.00 \mathrm{~m} \\
1660.15 \mathrm{~m}\end{array}$ & $\begin{array}{r}13.30 \mathrm{~m} \\
13.30 \mathrm{~m} \\
.10 .10 \mathrm{~m} \\
\end{array}$ & $\begin{array}{c}19.81 \mathrm{~m} \\
6.55 \mathrm{~m}\end{array}$ & $\begin{array}{l}154.18 \mathrm{~m} \\
155.45 \mathrm{~m} \\
163.03 \mathrm{~m}\end{array}$ & & \\
\hline & & $96.60 \mathrm{Ma}$ & Event P1 & $\begin{array}{l}\text { LO Prasinophyte phycomata (Influx 1) } \\
\text { INFLUX Litosphaeridium siphoniphorum } \\
\text { FO Litosphaeridium siphoniphorum I } \\
\text { FO Prasinophyte phycomata (Influx 1) }\end{array}$ & $\begin{array}{l}134.65 \mathrm{~m} \\
143.37 \mathrm{~m} \\
144.21 \mathrm{~m} \\
153.05 \mathrm{~m}\end{array}$ & $\begin{array}{l}74.63 \mathrm{~m} \\
76.88 \mathrm{~m} \\
77.74 \mathrm{~m} \\
80.52 \mathrm{~m}\end{array}$ & $\frac{1662.01 \mathrm{~m}}{1672.27 \mathrm{~m}}$ & $\begin{array}{c}\text { Not } \\
\text { sampled }\end{array}$ & $\begin{array}{l}9.60 \mathrm{~m} \\
5.18 \mathrm{~m} \\
0.01 \mathrm{~m} \\
0.01 \mathrm{~m}\end{array}$ & $\begin{array}{l}? 169.19 \mathrm{~m} \\
178.10 \mathrm{~m}\end{array}$ & & $\begin{array}{l}\text { Lincoln Shale } \\
\text { Member }\end{array}$ \\
\hline ower Cenom. & Buda Lst & & & LO Xiphophoridium alatum | & $157.23 \mathrm{~m}$ & $80.60 \mathrm{~m}$ & & & Not sampled & $184.53 \mathrm{~m}$ & & Thatcher Lst \\
\hline
\end{tabular}

Table S1. Correlation panel of Cenomanian and Turonian dinocyst and prasinophyte bioevents between Texas (TX) and Colorado (CO). 
The bioevents discussed in Eldrett et al. (2015) and Dodsworth (2016) for Iona-1 and Lozier Canyon respectively can be correlated with the other Eagle Ford Gr. sections documented in the present paper, and with the Portland-1 core and nearby Rock Canyon Anticline outcrop section, west of Pueblo (CO). Pueblo area lithostratigraphy is taken from Kauffman \& Pratt (1985). The Pueblo outcrop is the formally ratified Global boundary Stratotype Section and Point (GSSP) for the base of the Turonian Stage / lower Turonian substage (Kennedy et al. 2005), and the proposed GSSP for the base of the middle Turonian substage (Bengtson et al. 1996; Kennedy et al. 2000). These are dated as approximately 94.1 Ma and 92.9 Ma respectively by Eldrett et al. (2015). Pueblo ammonite zones are given next to the bed numbers in which phytoplankton bioevents occur; these are, in ascending order; (upper Cenomanian) Sciponoceras gracile (S.g.), Neocardioceras juddii (N.j.); (lower Turonian) Watinoceras coloradoense (W.c.), Mammites nodosoides (M.n.); (middle Turonian) Collignoniceras woollgari (C.w.). Pueblo palynological data are taken from Dodsworth (2000, beds 63 - 108; unpublished data, beds $109-125)$. Notes. The position of the base of the Turonian Stage in Portland-1 core is taken from Sageman et al. (2006), correlating with the GSSP outcrop base of Bed 86. * Indicates the stratigraphically highest sample analysed in a section. 'Low' next to a bioevent indicates a stratigraphically low occurrence relative to the other sections: In Iona-1, an isolated occurrence of Adnatosphaeridium tutulosum at $104.18 \mathrm{~m}$ is below the level of its Last Occurrence (LO) in the other sections; At Lozier Canyon, an influx of common Senoniasphaera rotundata at $44.18 \mathrm{~m}$ within the Langtry Member of the upper Eagle Ford Gr. is below the First Occurrence (FO) of common S. rotundata in the Austin Chalk in Iona-1 and Innes-1; At Pueblo, FO Consistent and FO Common Senoniasphaera turonica within the upper part of the lower Turonian, occur just below the base of the inter-regionally correlative 'Early-Middle Turonian Event' (EMTE) / 'Pewsey' carbon isotope feature, as picked here from the data of Pratt (1985; re-plotted in Kennedy et al. 2005, Fig. 10), between beds 118 and 121; in the TX sections Iona-1 and Innes-1, FO Consistent and FO Common S. turonica are stratigraphically higher, respectively within and above the "Middle Turonian Event' (MTE) carbon isotope feature in Iona-1, as picked by Eldrett et al. (2015), from 61.14m - 59.17m. The LO of Adnatosphaeridium? chonetum in Iona-1 is stratigraphically higher (basal Turonian) than at Pueblo (intra-upper Cenomanian).

\subsubsection{Palynological assemblage results}

\subsubsection{Southern KWIS (Texas)}

Palynological recovery in the Buda Limestone in the Iona-1 core is generally good with the limestone lithologies being characterized by low amorphous organic matter (AOM; 20\%) and associated higher recovery of 
palynomorphs $(\sim 30-50 \%)$ and phytoclasts $(\sim 20-40 \%)$. The palynomorph component is dominated by highly diverse marine dinocyst assemblages (Shannon-Weiner: $>2.7$; Simpson-Hunter: $>0.9$ ) with minor contribution from terrestrial pollen-spores $(<6 \%$; $<63$ counts per gram; c.p.g.). The dinocyst assemblage consists primarily of gonyaulacioid (G-) cysts, including Spiniferites ramosus group, Pterodinium cingulatum cingulatum and representatives of the Dapsilidinium and Florentinia genera. The marlstones are characterized by increased relative abundance of AOM (60-90\%), with the dinocyst assemblages showing slight increases in peridinioid (P-) cysts consisting of Palaeohystrichophora infusorioides and also the chorate dinocyst Cleistosphaeridium / Downiesphaeridium spp. Foraminiferal organic test linings are persistent throughout the Buda Limestone.

The sediments of the lower Eagle Ford Gr. as recovered from Iona-1, Innes-1 and well ' $\mathrm{X}$ ' cores record a shift in the kerogen composition compared to the underlying Buda Limestone, being characterized by high relative abundance of AOM and high relative and absolute abundances of green algal prasinophyte phycomata (see main text figures 4-6; and supplementary datafile). The dinocyst component of the assemblage records relatively low abundances with a high P:G ratio and a reduction in assemblage diversity (main text figures 4-6). P-cysts include Palaeohystrichophora infusorioides; specimens comparable to taxa informally described from Tarfaya, Morocco which are referred to as "Peridinioid sp. 1 \& 3" by Prauss (2012a) and Bosedinia sp. 1 \& 3 by Prauss (2012b; see section 1.5, below); Subtilisphaera spp. and Subtilisphaera (Corculodinium) inaffectum sensu Harris and Tocher (2003). In both Innes-1 and Iona-1 the interval corresponding with the lower part of the isotopic excursion assigned to the Middle Cenomanian Event (MCE) records a decline in the P:G ratio. In general, land-derived (terrigenous) pollen and spores remains a minor constituent of the palynological assemblage with low relative (T:M ratio: 0.1 ) and absolute abundances (<600 c.p.g) comprised primarily of gymnosperm pollen (bisaccate pollen and Classopollis) and angiosperm Normapolles (Atlantopollis and Complexiopollis) and tricolpate pollen.

In the middle part of the lower Eagle Ford Gr., a significant increase in the relative and absolute abundance of Bosedinia $c f . \operatorname{sp~} 1 \& 3$ is recorded in all three cores and corresponds to a minima in dinocyst assemblage diversity (Shannon-Weiner: 0.7; Simpson-Hunter: 0.3). As Bosedinia $c f$. sp $1 \& 3$ abundances decrease in the upper part of the lower Eagle Ford Gr., dinocyst diversity recovers and the palynological assemblage is characterized by overall low dinocyst abundances (comprised mainly of P-cysts) and the return of prasinophyte phycomata dominated assemblages. 
Upper Eagle Ford Gr. sediments recovered from Iona-1, Innes-1 and well ' $\mathrm{X}$ ' record a significant shift in palynological assemblages; notably the decline in prasinophyte phycomata and highly diverse (Shannon-Weiner: 3; Simpson-Hunter: 0.9) but generally low absolute abundance of marine dinocysts comprised primarily of Gcyst forms such as Spiniferites ramosus group, Pterodinium cingulatum cingulatum, Florentinia spp. and Oligosphaeridium spp. The upper Eagle Ford Gr. interval also records the first sporadic occurrence of the Cyclonephelium compactum-membraniphorum morphological plexus (Innes-1:52.95m; Iona-1:105.96m; well ' $\mathrm{X}$ ': $1638.5 \mathrm{~m}$ ), which becomes consistent with frequent abundance at the first peak of the OAE-2 CIE (point 'A' of Pratt and Threkheld, 1984). The OAE-2 interval in all three cores is also marked by the increase in foraminiferal test linings and an increase in the ratio of terrigenous palynomorphs to marine palynomorphs (T:M). The absolute abundance of terrigenous material remains relatively constant in Iona-1 and only slightly increases in Innes-1 ( 400 c.p.g) and well ' $\mathrm{X}$ ' ( 100 c.p.g) comprising mostly gymnosperm pollen. In both Iona-1 and Innes-1, the Langtry $\mathrm{Mb}$. is characterized by an increase in prasinophyte phycomata, with the basal boundary marked by a spike in terrigenous palynomorphs (max. 695 c.p.g; 71.15m), including pteridophyte spores. There is no recorded increase in terrigenous palynomorphs at the upper Eagle Ford-Austin Chalk contact in either Iona-1 or Innes-1.

The Austin Chalk interval is characterized by a reduction in AOM and an increase in foraminiferal test linings and highly diverse dinocyst assemblages dominated by G-cysts including Spiniferites ramosus group and Pterodinium cingulatum cingulatum.

The Bouldin Creek outcrop section (main text figure 7) shows similar trends to those described above. The analysed part of the Cloice Shale Mb. of the lower Eagle Ford Gr. is dominated by AOM ( 90\%); whilst the recovered dinocyst assemblage is primarily comprised of low diversity P-cyst forms including high abundance of Bosedinia $c f$. sp 1 \& $3(10.1 \mathrm{~m}-13.3 \mathrm{~m})$. Prasinophyte phycomata are relatively rare, although increase in abundance near the top towards the contact with the overlying Bouldin Flags Mb. Terrigenous palynomorphs abundances (400 - 1000 c.p.g) and foraminiferal test linings ( 100 c.p.g) are consistent in the Cloice Shale Mb. The Bouldin Flags interval is represented by a single sample analysed for palynology. This sample records a reduction in AOM quantity ( $70 \%)$, but with a relatively diverse dinocyst assemblage (Shannon-Weiner: $>3.4$; Simpson-Hunter: >0.9) characterized by an increased contribution by G-cyst forms $(\mathrm{P}: \mathrm{G}$ ratio $=0.7)$. The South Bosque Formation records similar diversity and dinocyst assemblages to the underlying Bouldin Flags; although prasinophyte phycomata abundances start to increase up-section. 


\subsubsection{Central KWIS (Colorado)}

The palynological assemblages recovered in the basal section of the USGS Portland-1 core (main text figure 8) encompassing the Dakota Sandstone $(213.36 \mathrm{~m}-208.97 \mathrm{~m})$ are characterized by high relative and absolute abundance of terrigenous palynomorphs (ave. T:M ratio $=0.7 ; 15,600$ c.p.g;) with dominant pteridophyte spores and frequent freshwater algae. The high terrigenous values decrease in the uppermost part of the Dakota Sandstone as marine dinocysts and prasinophyte phycomata increase in abundance. Dinocysts remain relatively abundant and diverse throughout the lower part of the Graneros Shale (207.31m - $186.75 \mathrm{~m})$, with persistent albeit low absolute abundance occurrences of foraminiferal test linings (ave. 100 c.p.g) and prasinophyte phycomata (ave. 280 c.p.g). The Thatcher Limestone interval through to the lower part of the MCE interval $(186.75 \mathrm{~m}-181.48 \mathrm{~m})$ records reoccurrence of abundant terrigenous palynomorphs comprising mostly gymnosperm pollen with subordinate but diverse occurrence of pteridophyte spores. This interval also records a slight increase in Bosedinia cf. sp $1 \& 3$ (ave. 150 c.p.g) although the dinocyst assemblages remain diverse (Shannon-Weiner: 2; Simpson-Hunter: >0.9) with variable contributions from G- and P-cysts (P:G ratio ranging from 0.3-0.7) such as Spiniferites ramosus group and Palaeohystrichophora infusorioides respectively. Samples from the Lincoln Shale interval (173.76m$163.03 \mathrm{~m}$ ) record increased relative abundance of $\mathrm{AOM}$ (ave. 70\%) and an increase in the abundance of prasinophyte phycomata and a less diverse dinocyst assemblage comprising a greater proportion of P-cysts (P:G ratio $\sim 0.8$ ). Absolute abundance of Bosedinia cf. sp $1 \& 3$ increases slightly but are still relatively low (ave. 370 c.p.g), while foraminiferal test lining and terrigenous palynomorph abundance decreases and remain low (100 and 500 c.p.g., respectively). The Hartland Shale interval $(160.07 \mathrm{~m}-149.45 \mathrm{~m})$ is characterized by maxima in relative AOM abundance (93\%) and absolute abundances of prasinophyte phycomata ( 3,100 c.p.g) and relatively low diversity dinocyst assemblages comprised mainly of P-cysts such as Bosedinia cf. sp $1 \& 3$ ( 2,300 c.p.g). As absolute abundance of Bosedinia cf. sp $1 \& 3$ decreases near the top of the Hartland Shale, the relative abundance of prasinophyte phycomata in the palynological assemblage increases. Foraminiferal test linings are only recorded outside the count in the Hartland Shale, with low abundances of terrigenous palynomorphs $(\mathrm{T}: \mathrm{M}$ ratio $=0.1)$. In contrast, the studied section of the Bridge Creek Mb. (147-90m-145.24m) records a decrease in AOM (ave. 54\%) and prasinophyte phycomata (ave. 170 c.p.g), with an increase in the occurrence of foraminiferal test linings and diverse dinocyst assemblages (Shannon-Weiner: >2; Simpson-Hunter: >0.9) comprising mostly G-cysts (P:G ratio: $<0.5)$ such as Pterodinium cingulatum cingulatum and representatives of the Spiniferites ramosus group. It is noted that the base consistent occurrence of the Cyclonephelium compactum-membraniphorum morphological plexus is recorded at $147.22 \mathrm{~m}$. 


\subsubsection{Demerara Rise}

Palynological recovery from ODP Sites 1260 and 1261 (main text figures 9-10) was generally low due to the high abundance of AOM $(\sim>90 \%)$. In order to obtain adequate concentrations of palynomorphs for counting Lycopodium tablets were not added, however this precluded the calculation of absolute abundances. The resultant palynomorph concentrations were sufficient for paleoenvironmental reconstructions and are reported as relative percentage abundances below.

At Site 1260 in the lower part of the studied interval (445.19 and 466.5 m.c.d; main text figure 9) the palynological assemblage is primarily comprised of relatively low diversity marine dinocysts (60\%; Shannon-Weiner: 1.3 ; Simpson-Hunter: 0.6). P-cysts domimate (P:G ratio: ave. 0.9) with Bosedinia cf. sp $1 \& 3$ comprising a significant proportion $(\sim 30 \%)$. Above this interval (corresponding with the isotopic excursion assigned to the MCE) there is a relative abundance increase of prasinophyte phycomata $(\sim 30 \%)$ as the dinocyst assemblages become more diverse, but with a continued contribution from Bosedinia $c f$. sp $1 \& 3$. Throughout the studied interval there is a greater contribution from terrigeneous palynomorphs (T:M ratio: ave. 0.3), whilst foraminiferal test linings are persistent but low relative abundance. During the OAE-2 CIE interval there is a recorded relative abundance decrease in prasinophyte phycomata and a slight increase in foraminiferal test linings. A drop in the abundance of AOM $(60 \%)$ is recorded from a single sample at $423.1 \mathrm{~m}$. There is also an increased contribution from dinocysts (65\%) with Bosedinia cf. sp 1 \& 3 remaining a significant component (up to $55 \%$ of the dinocyst assemblages).

A similar trend is also recorded at ODP Site 1261 with the pre-OAE-2 interval (467.995-637.585 m.c.d; main text figure 10) comprising of high relative abundances of prasinophyte phycomata (ave. 30\%), low diversity of dinocyst assemblages and low relative abundance of foraminiferal test linings $(\sim 5 \%)$. The change in palynological assemblages in the OAE-2 interval is sharp, with a significant drop in relative abundance of prasinophyte phycomata $(<10 \%)$ and a large increase in foraminiferal test linings ( $25 \%$ of palynomorphs). The dinocyst assemblages record a slight increase in diversity (Shannon-Weiner: 2; Simpson-Hunter: $\sim 0.8$ ), but with a continued contribution of Bosedinia cf. sp $1 \& 3(\sim 16 \%)$. 


\subsubsection{Kerguelen Plateau}

A diverse dinocyst assemblage (Shannon-Weiner: 3.2; Simpson-Hunter: $>0.9$ ) was recovered from Site 1138 (main text figure 11) The deepest sample analysed $(659.80 \mathrm{~m})$ records low recovery due to the dominant sandstone lithology, but contains representatives of Spiniferites and notably the first sporadic occurrence of the Cyclonephelium compactum-membraniphorum morphological plexus. G-cysts are abundant throughout the studied section, with Pterodinium cingulatum and Spiniferites ramosus group becoming more abundant up-section. Cyclonephelium compactum-membraniphorum morphological plexus also occurs throughout the studied interval, with a significant increase in abundance above $656.49 \mathrm{~m}$. Terrigenous pollen and spores comprise a minor component of the palynological assemblage $(\mathrm{T}: \mathrm{M}$ ratio $=<0.1)$.

\subsection{Notes on dinocyst genus Bosedinia}

\subsubsection{Taxonomic comments}

Genus Bosedinia (He,1984) Chen et al.1988 emend. Prauss, 2012c

In Cenomanian to Conician marine deposits at Tarfaya, Prauss (2012a, 2012b, 2012c) discriminated relatively

simple spheroidal-shaped peridinioid dinocysts from algal leiospheres, based mainly on the presence of omphali (bio-polymeric 'accumulation bodies' of Evitt, 1985) inside and, in occasional rare specimens, a regular operculum outline which allows attribution to the genus Bosedinia. He reported that specimens often occur in dense clusters, probably reflecting phytoplankton blooms.

As first noted by Eldrett et al. (2015) then Dodsworth (2016), Bosedinia is also present in the Cenomanian to Conician marine deposits in the KWIS (Texas and Colorado). Smaller laevigate specimens $(20-40 \mu \mathrm{m})$ with subspheroidal shape, lack of cavation, and when present a combination intercalary-apical archaeopyle with fused paraplate operculum, are comparable to the Tarfaya specimens of 'Perdinioid sp.1' / 'Bosedinia sp.1', informally described by Prauss (2012a, 2012b). Larger laevigate specimens ( $>40 \mu \mathrm{m})$ are comparable to his 'Perdinioid sp.3' / 'Bosedinia sp.3'. The KWIS and Demerara Rise specimens contain fewer omphali (usually one or none) and are referred to as Bosedinia $c f$. sp $1 \& 3$ in this report. Bosedinia specimens ornamented with verrucae (Bosedinia sp. $2[20-40 \mu \mathrm{m}]$ and Bosedinia sp. 4 [>40 $\mu \mathrm{m}]$ of Prauss 2012b) have not been observed from the KWIS, although occasional specimens with grana have been noted, but verrucate specimens are consistently present at the Demerara Rise sites. Rare examples of individual intercalary plates were noted and photographed (Plate 1) on some Demerara Rise specimens of Bosedinia. Palynomorph swelling due to laboratory oxidation possibly 
contributed to intercalary plates breaking up on occasional specimens of Bosedinia (they are usually fused together), rather than indicating assignment to another peridinioid genus (cf. Schrank, 1988).

\subsubsection{Broader geographic and stratigraphic distribution}

5 Dinocysts with relatively simple morphology assigned to Bosedinia were first described from lacustrine deposits of Oligocene - Neogene age in the South China Sea (He, 1984; Cole, 1992) where they are associated with common occurrences of the fresh- / brackish water algae Pediastrum and Botryococcus, and an absence of microfauna. In addition to the marine records of Bosedinia from Tarfaya, KWIS and Demerara Rise discussed in the main paper, our unpublished work on the elsewhere (i.e. Oil Shale in Jordon) recorded abundant occurrences of Bosedinia cf. sp 1, 2, 3 \& 4 in some samples, in association with Campanian - Maastrichtian 'Malloy suite' marker P-cysts (see section 1.6, below) and an absence of fresh- / brackish-water algae. The assemblages are presumed reworked into Eocene deposits, based on nannofossil evidence (Alqudah et al. 2014). Makled et al. (2014) suggested nutrient upwelling from the tethyan Levant upwelling system as a mechanism for stimulating palaeoproductivity of P-cysts during deposition of the Jordon Oil Shale and contiguous organic-rich deposits in Egypt. Boltenhagen (1977) illustrated possible Bosedinia specimens in Upper Cretaceous material from Gabon; single specimens were recorded as Leiosphaeridia sp. A, and clusters as Acritarcha subgroup Incertae. The prominent omphali present on his illustrated specimens supports their re-assignment to Bosedinia. It is likely that other authors have attributed Bosedinia to algal leiospheres or acritarchs; in the central KWIS, Harris \& Tocher (2003) assigned clusters of specimens with omphali to the acritarch taxon Eyrea nebulosa Cookson \& Eisenack 1970 but these may be Bosedinia as they do not appear to have kalypta typical of E. nebulosa (corresponding photographic illustrations are found in the unpublished Ph.D. thesis of A.J. Harris, 1996 [Plate 43], University of Wales, Aberystwyth). Illustrations of candidate Bosedinia specimens have not been found by us in arctic/boreal KWIS or European literature, suggesting their abundant occurrence may be mainly confined to middle and in particular lower latitude regions during the Late Cretaceous. They are notably absent from the high latitude southern hemisphere Kerguelen Plateau Site 1138 samples reported in this paper. The occurrence of Bosedinia in the lacustrine and marine deposits reviewed here, including the marine organic-rich shales in low latitude tethyan realm sites that contain few or no fresh-water algae, are consistent with a broad range of salinity and oxygen tolerance. 
Plate 1
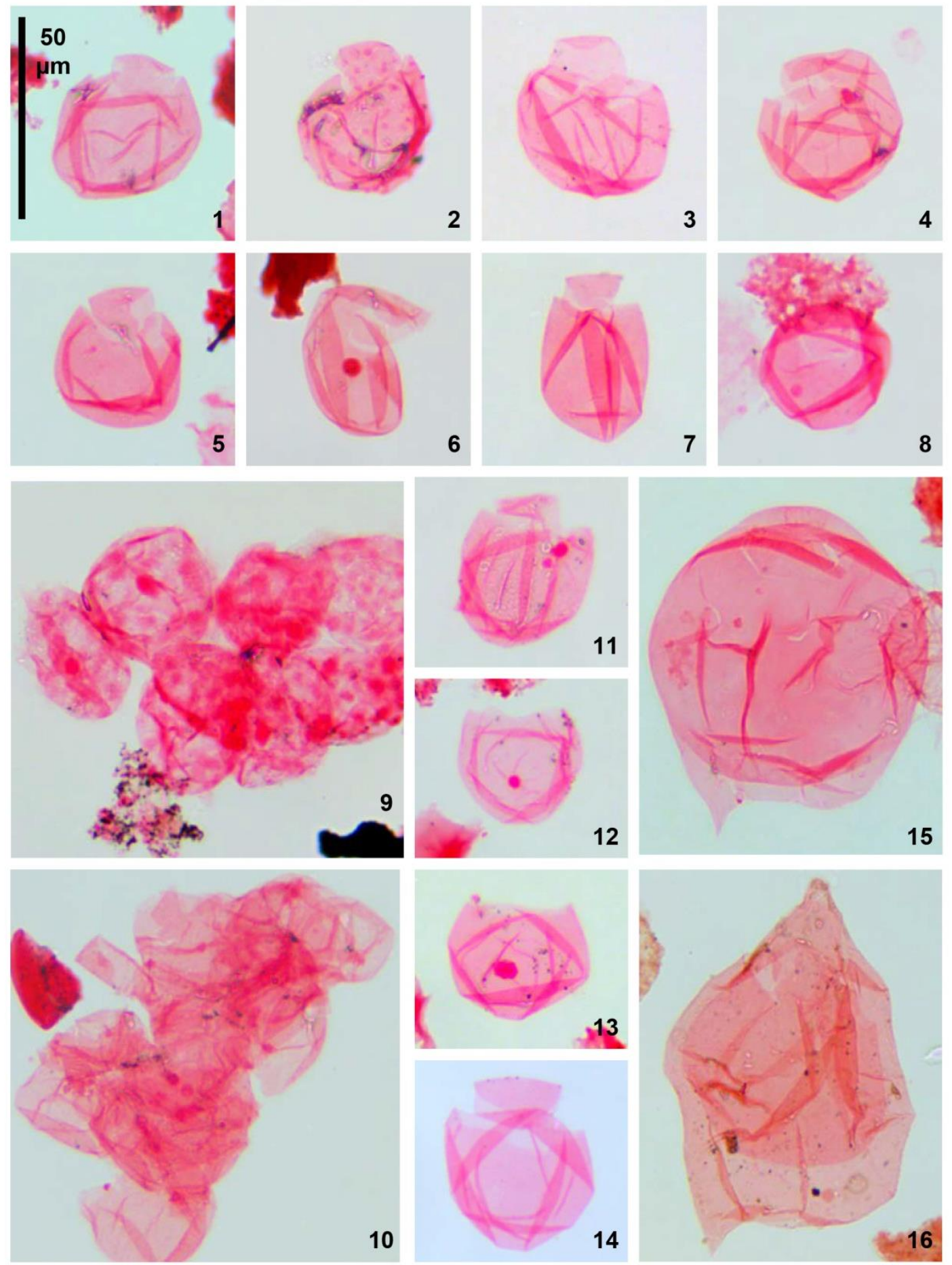

Plate 1. Peridinioid dinocysts (P-cysts) from ODP Leg 207, Sites 1260 \& 1261A, Demerara Rise, and Bouldin Creek outcrop (AU-2), near Austin, Texas. Measured composite depths (MCD) are given for core samples while heights above base of sampled section are given for outcrop samples. England Finder references for specimen positions on microscope slides are also given. All figures are to the same scale (see $50 \mu \mathrm{m}$ scale bar).Tethyan Realm P-cysts, tentative archaeopyle / operculum interpretations are given for individual specimens: 
Figs. 1, 3-8 and 10-14, Bosedinia cf. sp $1 \& 3$ of Prauss (2012b) (laevigate), 1. 1260, 444.19 m, M47/3: Suture at junction of tA \& tI plates, operculum attached (?1a intercalary plate free). 3. 1260, 427.84 m, D41/1: Intercalary archaeopyle (separated 1a+2a+3a plates attached). 4. 1260, $425.48 \mathrm{~m}, \mathrm{U} 43 / 3$ : Intercalary archaeopyle (2a+3a plate attached with sutures between them, 1a plate free). 5. 1260, $445.19 \mathrm{~m}, \mathrm{~W} 41 / 4$ : Suture at junction tAtI plates, one plate intercalary archaeopyle (3a plate free). 6. $1260,426.33 \mathrm{~m}, \mathrm{X} 35 / 1$ : Intercalary archaeopyle $(1 \mathrm{a}+2 \mathrm{a}$ plates attached, 3a plate free). 7. 1260, $425.17 \mathrm{~m}, 042 / 0$ : Intercalary archaeopyle (2a plate attached with suture but 1a+3a plates free). 8. 1260, 450.82 m, U37/3: Intercalary(?) archaeopyle suture. 10. 1261A, 629.64 m, W28/0: Cluster of specimens. 11. 1260, $450.82 \mathrm{~m}, \mathrm{~L} 48 / 4$ : Suture at junction of tAtI plates, intercalary archaeopyle, detail uncertain. 12. 1260, 450.82 m, R46/2: Archaeopyle tAtI, operculum free. 13. 1260, 450.82 m, M46/0: Archaeopyle tAtI, operculum free. 14. 1261A, $636.60 \mathrm{~m}, \mathrm{L45} / 4$ : Archaeopyle tI, all three intercalary plates free. Figs. 2 \& 9, Bosedinia cf. sp 2 \& 4 of Prauss (2012b) (verrucate), 2. 1260, 425.4 8m, V39/0: Intercalary archaeopyle (2a+3a plates attached with sutures between them, 1a plate free). 9. 1260, $422.02 \mathrm{~m}$, P33/0: Cluster of specimens. Note that the very rare examples of individual intercalary plates photographed here on some Demerara Rise specimens may have been caused by palynomorph swelling due to laboratory oxidation, resulting in intercalary plates breaking up on occasional specimens of Bosedinia (they are usually fused together), rather than assignment to another peridinioid genus (cf. Schrank, 1988). Boreal Realm P-cysts: Fig. 15. Eurydinium glomeratum, AU-2, 660 cm, O39/3; Fig. 16. Isabelidinium magnum, AU-2, $950 \mathrm{~cm}, \mathrm{R} 14 / 2$. Note that both specimens are morphologically closely comparable to the type material illustrated from Saskatchewan, Canada by Davey (1970).

\subsection{Peridinioid dinocyst and ammonite provincialism}

Lentin and Williams (1980) distinguished three Upper Cretaceous peridinioid dinocyst (P-cyst) provincial 'suites' based on their paleogeographic (mainly paleolatitudinal) distribution during the Campanian, derived largely from datasets in North and South America; the McIntyre suite which is arctic-boreal in distribution; the Williams suite in warm temperate areas and the Malloy suite, restricted to the tropical-subtropical paleolatitudinal belt. Costa and Davey (1992) recognised the former two suites in Europe from upper Cenomanian to Campanian deposits. McIntyre assemblages characterised by Laciniadinium and large species of Chatangiella and Isabelidinium roughly coincide with the siliciclastic Shetland Group in the northerly North Sea and Norwegian Sea. Williams suite assemblages characterised by species of Alterbidium, Spinidinium, Trithyrodinium and smaller species of Chatangiella and Isabelidinium roughly coincide with the limestone Chalk Group in the central and southern North Sea and onshore England and France. The Cenomanian and Turonian pre-dates the inception of Lentin and Williams' (1980) tropical-subtropical species of Andalusiella, Cerodinium, Lejeunecysta and Senegalinium. The presence of elater-bearing pollen at the Demerara Rise sites analysed here is consistent with the tropicalsubtropical location (see below). As noted by van Helmond et al. (2016; Figure 1), other high resolution 
proto-Atlantic. This probably mainly reflects widespread proximal depositional facies on African and South American margins during opening of the proto-Atlantic; papers that cover dinocysts from the interval are broad sample resolution (e.g. Arai et al. 2000; ODP, including Site 364; Morgan, 1978) or deal mainly with taxonomy (e.g. Jain and Millepied, 1973). The continuous presence of Bosedinia at the Demerara Rise sections investigated here compares well with other marine tethyan Realm sites in northern-western Africa (Tarfaya and possibly Gabon; Section 1.5).

The upper Eagle Ford Gr. (Texas) and Lower Bridge Creek Limestone Mb. (Colorado) dinocyst assemblages reported here are broadly comparable to those from western European Chalk Group facies as summarised by Costa and Davey (1992), including diversified G-cysts and prominent Williams suite type P-cyst assemblages. From published North American and European data, along with data presented here, it is apparent that some P-cysts which are present in high abundances in the boreal region are found in lower numbers further south in more temperate zones and are absent from the tropical-subtropical zone at Demerara Rise. In deposits assigned to a late Cenomanian to middle Turonian age in Alberta and Saskatchewan, western Canada, i.e. the uppermost Belle Fourche Formation and Second White Specks Formation, Bloch et al. (1999) noted the first appearance and subsequent dominance in dinocyst assemblages of two large species of P-cyst, Isabelidinium magnum and Eurydinium glomeratum. Our unpublished data from two samples in the coeval Favel Formation in Manitoba, western Canada, confirms superabundant Eurydinium glomeratum and frequent Isabelidinium magnum around the same latitude. I magnum has a comparable stratigraphic range further south in the KWIS but it occurs in lower numbers. It is rare to frequent throughout the upper Cenomanian to middle Turonian strata at Pueblo, Colorado, with an abundant influx there in higher parts of the lower Turonian (M. nodosoides Ammonite Zone; Dodsworth, 2000). It is also rare to frequent in occurrence in the upper Eagle Ford Gr. in Texas (see below) but is not recorded from Demerara Rise, Sites 1260 and 1261 (this paper). In Europe, an upper Turonian influx of I. magnum occurs in the northerly Shetland Group (Costa \& Davey, 1992), at a higher level than the influx at Pueblo, while the taxon is generally rare or absent in the southerly Chalk Group. E. glomeratum has a comparable stratigraphic distribution to I magnum in Alberta and Saskatchewan (Bloch et al. 1999) but first occurs at higher stratigraphic level, around the lower Turonian W. coloradoense - M. nodosoides Ammonite Zone boundary, at Pueblo, Colorado and Bunker Hill, Kansas (Harris \& Tocher, 2003). It is common in the upper part of the M. nodosoides Zone, from Bed 112, and in the overlying middle Turonian interval at Pueblo (C. woollgari Ammonite Zone; Table S1). In the upper 
to the lower-middle Turonian interval in Iona-1. E. glomeratum was not recorded at Demerara Rise, Sites 1260 and 1261 (this paper).

Occurrences of boreal P-cysts in Colorado and Texas support the case presented by Eldrett et al. (2014) and van Helmond et al. (2016) for the G-cyst Cyclonephelium compactum-membraniphorum plexus (Ccm) migrating southwards with an incursion of cooler seawater from the north during the Plenus Cold Event (PCE). Persistent occurrences of Isabelidinium magnum in the upper part of the Hartland Shale Mb. (from 154.18m in the Portland1 core; this paper) and overlying Lower and Middle Bridge Limestone Creek Mbs. (Dodsworth, 2000) at Pueblo, Colorado; and from around the base of the upper Eagle Ford Gr. in Iona-1 and Innes-1, Texas (108.77m and $52.43 \mathrm{~m}$ respectively; Table S1) are consistent with a cooling trend. However, I. magnum is also sporadically recorded from the lower Eagle Ford Gr. in Iona-1 and Lozier Canyon. Its migration southward seems to pre-date that of $\mathrm{Ccm}$ and may have occurred during onset cooling prior to that culminating in the PCE.

The main southward migration of boreal P-cysts at Pueblo, i.e. the influx of abundant Isabelidinium magnum and the persistently common occurrence of Eurydinium glomeratum in the higher part of the lower Turonian and the middle Turonian, post-dates the PCE and probably occurred after subsequent global warming close to the Cenomanian-Turonian boundary (e.g. Huber et al. 2002), the "early Turonian thermal maximum” of Pearce et al. (2009) and Jarvis et al. (2011). In the Eagle Ford Gr. cores, there is no obvious correlative influx of boreal P-cysts around the lower-middle Turonian boundary, although as noted above E. glomeratum is relatively persistent around that level in Iona-1 (88.87 to $70.45 \mathrm{~m})$. The apparent southward reduction in numbers of I. magnum and E. glomeratum between western Canada, Colorado and Texas mirrors that of I. magnum between the Shetland Group and Chalk Group in Europe and probably reflects increased sea surface temperature in warmer temperate paleolatitudes. Cobban (1984) also reported Cenomanian-Turonian boreal ammonite genera such as Dunveganoceras and Scaphites having a typically northern KWIS distribution while genera such as Vascoceras, Nigericeras, Romaniceras and Thomasites that are of value for correlation with tethyan sequences, are mostly confined to the southernmost part of the KWIS. However, the continuous albeit mainly rare presence of boreal Pcysts in upper Cenomanian and Turonian strata at least as far south as Texas, along with associated high diversity G-cyst assemblages, is support for our interpretation of unrestricted/open marine oxygenated water-mass from a northerly source. Kennedy et al. (1987) also noted the presence of boreal ammonite faunas as far south as west Texas in intra-lower Turonian strata (Pseudaspidoceras flexuosum Ammonite Zone). It is also noteworthy that $I$. 
magnum is at its highest relative abundance in Iona-1 in the Austin Chalk (frequent in occurrence from 18.70m to $7.91 \mathrm{~m}$ ), supporting our interpretation of re-introduction of cooler waters of northerly origin during the deposition of that limestone facies in west Texas.

\subsection{Pollen provincialism}

Herngreen and Chlonova (1981), Herngreen et al. (1996) and Traverse (2007) summarised pollen provincialism during the Late Cretaceous; an arctic-boreal Aquilapollenites province extending southwards to mid-continent North America and westward to eastern Asia; conversely a Normapolles province also mid-continent North America but extending eastward to Europe and western Asia. Samples analysed in this study from the Eagle Ford Gr. in Texas, and by Christopher (1982) and Dodsworth (2016), recovered Normapolle pollen genera Complexiopollis and Atlanopollis; rare specimens of these taxa were also reported from Pueblo, Colorado (Dodsworth, 2000). Significantly, triprojectate Aquilapolle pollen are only occasionally recorded from these localities, possibly due to relatively southerly positions within the KWIS and/or pre-dating of establishment of corresponding floras within the KWIS which Nichols and Sweet (1993) indicated as occurring during Santonian time, later than Turonian time suggested by Herngreen and Chlonova (1981). In Europe, Costa and Davey (1992) reported the southerly limit of triprojectate pollen approximately coinciding with the distribution of dinocyst associations of arctic-boreal affinities in the siliciclastic Shetland Group while Dodsworth $(1996,2000)$ reported rare Normapolles pollen (mainly Complexiopollis), from the eastern and southern England Chalk Group and an offshore southern North Sea oil well (UK 47/10-1). Normapolles pollen are a common component of palynological assemblages further south in Europe (e.g. Spain; Peyrot, 2011, 2012; Romania; Ion et al. 2004). The pollen records from Texas and Colorado indicate assignment of the sections investigated here to the Normapolles province. Herngreen and Chlonova (1981) distinguished a third low-latitude Palmae province which is delineated by the distribution of elater-bearing gymnosperm pollen and the genus Afropollis, and a fourth, higher latitude southern hemisphere (austral) Nothofagidites province. Elater-bearing pollen were only recorded from Demerara Rise Sites 1260 and 1261 in the present study, and they were also noted in the underling Albian interval from Site 1260 by Krauspenhar et al. (2014), confirming assignment of the sections to the tropical-subtropical Palmae province.

The occurrence of mainly pteridophyte/bryophyte spores in the terrigenous palynological assemblage of the Kerguelen Plateau Site 1138 samples analysed here relates to the palaeogeographic setting, i.e. the relatively cool temperate high latitude (antarctic) floral province of the Kerguelen Plateau during mid-Cretaceous times (cf. Mohr 
et al. 2002). Mohr et al. noted a dominance of pteridophyte/bryophyte spores over gymnosperm pollen (mainly Classopollis [Corollina]) throughout the Albian, Cenomanian, Turonian and Coniacian interval at Site 1138.

\subsection{Sequence Stratigraphic interpretations}

The Eagle Ford Gr. represents a $3^{\text {rd }}$-order transgressive-regressive cycle, termed Eagle Fordian by Pessagno (1969) and equivalent to the Greenhorn Cycle in the central KWIS (after Kauffman, 1984). The Eagle Ford sequence stratigraphic framework was further characterized at the ca. 58-m-thick Lozier Canyon outcrop in Terrell County, west Texas (see Donovan \& Staerker 2010; Donovan et al. (2012) with the definition of four fourth order depositional sequences: K63 (Lozier Canyon Member), K64 (Antonio Creek Member), K65 (Scott Ranch Member) and K70 (Langtry Member). In general, each fourth-order sequence consists of a lower portion dominated by organic-rich carbonate mudstones and an upper portion consisting of carbonate mudstones with limestone interbeds, which are interpreted respectively as transgressive and highstand deposits reflecting variations in relative sea-level (Donovan \& Staerker 2010; Donovan et al. 2012). However, subsequent foraminiferal (Lowery et al. 2014) and palynological (Dodsworth, 2016) studies on the Lozier Canyon section have not fully corroborated the sequence stratigraphic interpretation. In particular, in the Eagle Ford Gr., Lowery et al. (2014) found no microfossil evidence for sequence boundaries between i) the Lozier Canyon Member (K63) and the Antonio Creek Member (K64) and ii) the Antonio Creek Member (K64)-Scott Ranch Member (K65). Furthermore, the palynological data does not show any shifts in the ratio between terrestrial and marine palynomorphs across these proposed sequence boundaries that may indicate marked sea level change. An interval of prominent prasinophyte phycomata (>75\% of the palynological assemblage) in the Antonio Creek Member (K64) at Lozier Canyon is also present at the same stratigraphic level in the Iona-1 and Innes-1 cores (Influx 2 in Table S1) and may reflect oxygen-deficient waters in the photic zone (see Prauss, 2007), resulting from lower sea levels relative to immediately underlying strata, as suggested by Dodsworth (2016). However, in this contribution the increase in prasinophyte phycomata is interpreted to more likely reflect the northward migration of an equatorial Atlantic tethyan water-mass into the KWIS during a period of overall sea level rise (see main text discussion). The sequence stratigraphic interpretation presented in this paper is different from that presented by Donovan \& Staerker (2010) and Donovan et al. (2012) as discussed below and presented in Figure S1.

The contact between the Buda Limestone and Eagle Ford Gr. is erosional and unconformable. Based on the biostratigraphic data, the hiatus between the two formations is constrained to the early Cenomanian, and a linear 
extrapolation between geochronological events and the astronomical age model for Iona-1 core indicate duration of $\sim 0.41 \mathrm{Myr}$ with resumption of deposition marking the base of the Eagle Ford Gr. occurring at 97.05 $\pm 0.12 \mathrm{Ma}$ (see Eldrett et al. 2015a). This contact defines a regional sequence boundary overlying the high-stand systems tract of the Buda Limestone. The lowermost Eagle Ford Gr., is characterized by sigmoidal-cross stratification which is later substituted by hummocky cross stratification and transitions to limestone-marlstone couplets indicative of transgressive systems tract (see Minisini et al. in review for details). These rhythmical lithological alternations between limestone and marlstone have been demonstrated to reflect climate-driven cycles related to Earth-Sun dynamics without the need to invoke significant sea-level variations (Eldrett et al. 2015b). The palynological data presented here, combined with foraminiferal assemblages and sedimentological descriptions in both cores and outcrops (see Minisini et al., in review) provide no evidence for sea-level variations and provides no support for the placement of a sequence boundary within the lower Eagle Ford Fm. (equivalent to the K63-K64 boundary of Donovan et al. 2012). As such the palynological assemblage data reflects oceanographic and climatic variations that support the microfossil evidence (Lowery et al. 2014) and are entirely consistent with a Greenhouse Earth System characterizing the Cenomanian-Turonian stages, in which the magnitude and rate of sea level change would have been significantly reduced $(<10-20 \mathrm{~m}$ over periods of 10-400kyr; see review in Haq, 2014; Sames et al. 2016) compared to Icehouse conditions of the Late Cenozoic. The maximum flooding surface is picked in the lower part of the upper Eagle Ford based on peak abundances of planktonic foraminifera (unpublished) and dinocysts (this study) and thickening sedimentological cycles (Minisini et al. in review). The overlying strata are interpreted as representing a high-stand systems tract, marked by a regional unconformity at the base of the Langtry Member. In Iona-1 the duration of this hiatal interval is estimated $\sim 180 \mathrm{ka}$ (Eldrett et al. 2015a); whereas in both Innes-1 and Lozier Canyon (see Lowery et al. 2014) the top of the OAE-2 interval is missing in this unconformity (ca. $2 \mathrm{Ma}$ ). The Langtry Mb. of the Eagle Ford Gr., is interpreted to represent a transgressive systems tract culminating in a maximum flooding surface in the Austin. However, even though the Eagle Ford-Austin contact is interpreted as conformable in the Innes and Iona cores, the increase in bivalves, shell fragments, echinoids and sediments recording symmetric ripples and some chaotic units may represent a regressive episode near the top of the Eagle Ford Gr. (see Minisini et al. in review), or be related to increase current activity independent of sealevel. A hiatal surface at the Eagle Ford-Austin contact is apparent in the Lozier Canyon section (Lowery et al. 2014), in the subsurface in the Maverick Basin, Texas (unpublished data); and further to the north in the central KWIS (e.g. Hattin, 1975; Kauffman and Caldwell, 1993), and thus may reflect a regional sequence boundary. 
Further investigations into the nature of the Eagle Ford- Austin Chalk contact is recommended to determine its origin and extent.

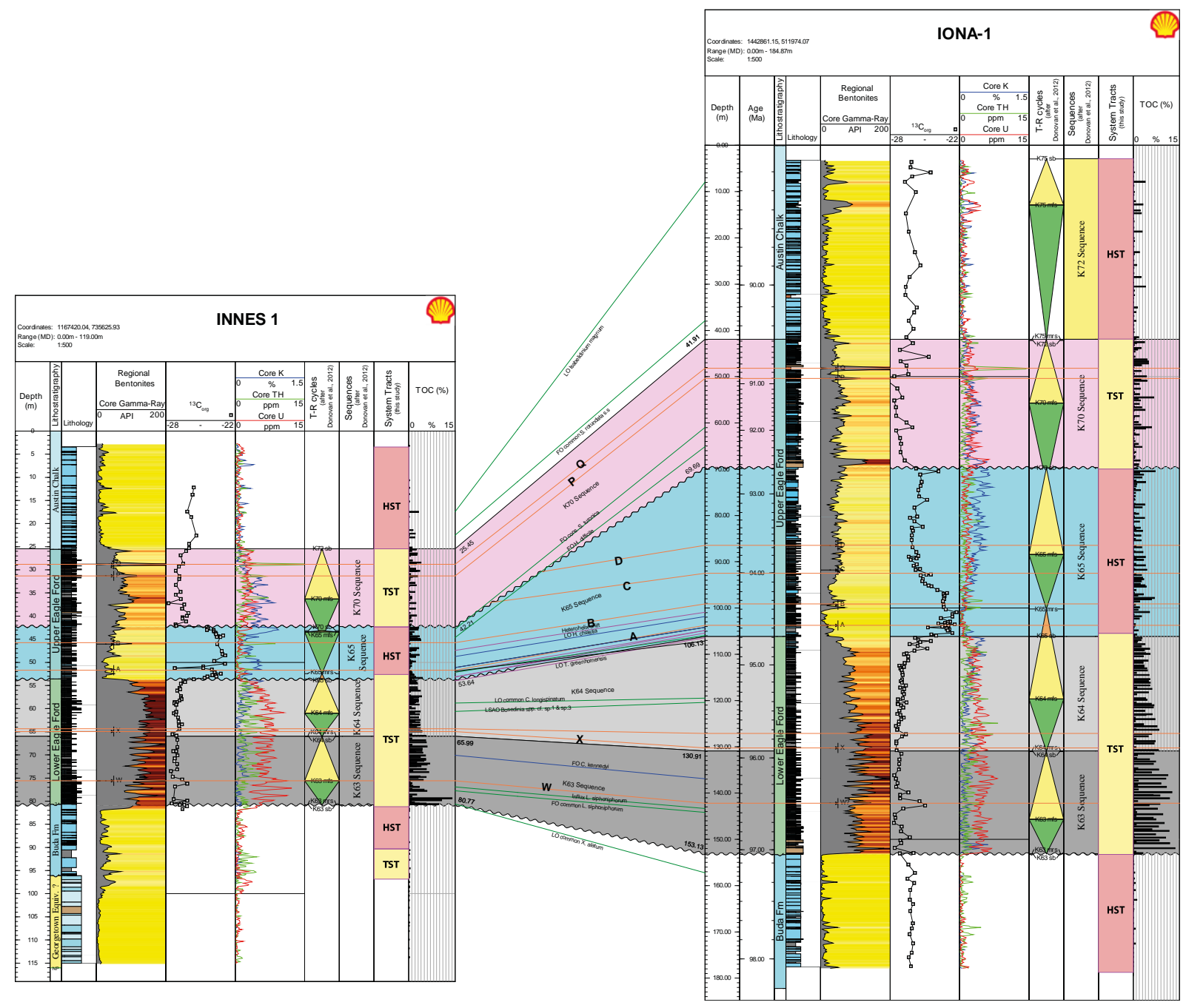

Figure S1. Sequence stratigraphic interpretation for the Innes and Iona cores. Correlation ties based on bio-events:

nannofossils (blue); foraminifera (purple), dinocysts (green), regional bentonites (orange; labelled in bold). Transgressive-Regressive (T-R) cycle column following interpretation of Donovan et al. (2012; through correlation with Lozier outcrop section); nomenclature: SB = sequence boundary; MFS = Maximum Flooding Surface; MRS = Maximum Regressive Surface; colours: green= transgressive systems tract; yellow= highstand systems tract; orange = lowstand systems tract. K sequences after Donovan \& Staerker (2010) and Donovan et al. (2012). However, sequence stratigraphic interpretations of Donovan \& Staerker (2010) and Donovan et al. (2012) not supported here; alternative sequence stratigraphic interpretation presented: System tracts column; nomenclature: HST = highstand systems tract; TST = transgressive systems tract 


\section{References.}

Alqudah, M., Hussein, M.A., Podlaha, O.G.,Van den Boorn, S., Kolonic, S., Mutterlose, J. 2014. Calcareous nannofossil biostratigraphy of Eocene oil shales from central Jordan. GeoArabia, 19.

Arai, M., Neto, B.J., Lana, C.C., Pedrão, E. 2000. Cretaceous dinoflagellate provincialism in Brazilian marginal basins. Cretaceous Research, 21: 351-366.

Algeo, T.J., Morford, J., and Cruse, A., 2012. New applications of trace metals as proxies in marine environments: Chemical Geology, v. 306-307, p. 160-164, doi:10.1016/j.chemgeo.2012.03.009.Bloch, J.D., SchroderAdams, C.J., Leckie, D.A., Craig, J., McIntyre, D.J. 1999. Sedimentology, micropaleontology, geochemistry, and hydrocarbon potential of shale from the Cretaceous Lower Colorado Group in western Canada. Geological Survey of Canada, Bulletin 531.

Bengtson, P., Cobban, W.A., Dodsworth, P., Gale, A.S., Kenndey, W.J., Lamolda, M.A., Matsumoto, T., Reyment, R.A., Seibertz, E., Tröger, K.-A. 1996. The Turonian stage and substage boundaries. Pp. 69-79 in Rawson et al. (editors) Proceedings, "Second International Symposium on Cretaceous Stage Boundaries", Brussels 8-16 September 1995. Bulletin de l'Institut Royal des Sciences Naturelles de Belgique - Sciences de la Terre, No. 66.

Bloch, J.D., Schroder-Adams, C.J., Leckie, D.A., Craig, J., McIntyre, D.J. 1999. Sedimentology, micropaleontology, geochemistry, and hydrocarbon potential of shale from the Cretaceous Lower Colorado Group in western Canada. Geological Survey of Canada, Bulletin 531.

Boltenhagen, E. 1977. Microplancton du Crétacé Supérieur du Gabon. Cahiers de Paléontologie: Unnumbered, p.1-150, pl. 1-25.

Bowman, A.R and Bralower, T.J. 2005. Paleoceanographic significance of high-resolution carbon isotope records across the Cenomanian-Turonian boundary in the Western Interior and New Jersey coastal plain, USA. Marine Geology, 217, 305-321.

Brumsack, H.J. 2006. The trace metal content of recent organic-rich sediments: Implications for the Cretaceous black shale formation. Palaeogeogr. Palaeoclimatol. Palaeoecol. 232, 344-361.

Christopher RA. 1982. The occurrence of the Complexiopollis-Atlanopollis zone (Palynomorphs) in the Eagle Ford group (Upper Cretaceous) of Texas. J Paleontol. 56:525-541.

Cobban, W.A. 1984. Mid-Cretaceous ammonite zones, Western Interior, United States. Bull. Geol. Soc. Denmark 33: 71-89.

Cole, J.M. 1992. Freshwater dinoflagellate cysts and acritarchs from Neogene and Oligocene sediments of the South China Sea and adjacent areas. In Head, M.J. and Wrenn, J.H. (eds.) Neogene and Quaternary Dinoflagellate Cysts and Acritarchs. AASP Foundation, Dallas: 181-196.

Costa, L.I., Davey, R.J. 1992. Dinoflagellate cysts of the Cretaceous System. In, Powell, A.J. (Ed.) A Stratigraphic Index of Dinoflagellate Cysts. Chapman \& Hall, London.

Dale, B., Fjellså, A., 1994. Dinoflagellate cysts as paleoproductivity indicators: state of the art, potential and limits. In: Zahn, R., Pedersen, T.F., Kaminski, M.A., Labeyrie, L. (Eds.), Carbon Cycling in the Glacial Ocean: Constraints on the Ocean's Role in Global Change. Springer, Berlin, pp. 521-537.

Davey, R.J. 1970. Non-calcareous microplankton from the Cenomanian of England, northern France and North America, Part II. Bulletin of the British Museum (Natural History) Geology 18(8): 333-397 
Dickson, A.J., Saker-Clark, M., Jenkyns, H., Bottini, C., Erba, E., Russo, F., Gorbanenko, O., Naafs, D.B.A., Pancost, R.D., Robinson, S.A., Van den Boorn, S., Idiz, E. 2016. A Southern Hemisphere record of global trace-metal drawdown and orbital modulation of organic-matter burial across the Cenomanian-Turonian boundary (Ocean Drilling Program Site 1138, Kerguelen Plateau). Sedimentology. Accepted Author Manucript doi: 10.1111/sed.12303

Dodsworth, P. 1995. A note of caution concerning the application of quantitative palynological data from oxidized preparations. Journal of Micropalaeontology 14: 6.

Dodsworth, P. 1996. Stratigraphy, microfossils and depositional environments of the lowermost part of the Welton Chalk Formation (late Cenomanian to early Turonian, Cretaceous) in eastern England. Proceedings of the Yorkshire Geological Society 51: 45-64.

Dodsworth P. 2000. Trans-Atlantic dinoflagellate cyst stratigraphy across the Cenomanian-Turonian (Cretaceous) stage boundary. J Micropalaeontol. 19:69-84.

Dodsworth, P. 2004. The palynology of the Cenomanian - Turonian (Cretaceous) boundary succession at Aksudere in Crimea, Ukraine. Palynology 28: 129-141.

Dodsworth, P. 2016. Palynostratigraphy and palaeoenvironments of the Eagle Ford Group (Upper Cretaceous) at the Lozier Canyon outcrop reference section, west Texas, USA. Palynology, 40: 357-378. doi 10.1080/01916122.2015.1073188

Donovan, A.D. and Staerker, T.S., 2010. Sequence stratigraphy of the Eagle Ford (Boquillas) Formation in the subsurface of South Texas and outcrops of West Texas. Gulf Coast Association of Geological Societies Transactions 60: 861-899.

Donovan, A.D., Staerker, T.S., Pramudito, A., Weiguo, L., Corbett, M., Lowery, C.M., Romero, A.M., Gardner, R.D. 2012. The Eagle Ford outcrops of West Texas: A laboratory for understanding heterogeneities within unconventional mudstone reservoirs. GCAGS Journal 1: 162-185.

Du Vivier, A.D.C., Selby, D., Sageman, B.B., Jarvis, I., Gröcke, D.R., and Voigt, S., 2014, Marine 187Os/188Os isotope stratigraphy reveals the interaction of volcanism and ocean circulation during Oceanic Anoxic Event 2: Earth and Planetary Sci.Letters, v. 389, p. 23-33, doi:10.1016/j.eps1.2013.12.024.

Eldrett, J.S., Minisini, D., Bergman, S.C. 2014. Decoupling of the carbon cycle during Oceanic Anoxic Event 2. Geology, 42: 567-570.

Eldrett, J.S., Ma, C., Bergman, S.C., Lutz, B., Gregory, F.J., Dodsworth, P., Phipps, M., Hardas, P., Minisini, D., Ozkan, A. and Ramezani, J., 2015. An astronomically calibrated stratigraphy of the Cenomanian, Turonian and earliest Coniacian from the Cretaceous Western Interior Seaway, USA: Implications for global chronostratigraphy. Cretaceous Research, 56, pp.316-344. doi: 10.1016/j.cretres.2015.04.010

Erbacher, J., Friedrich., Wilson, P., Birch, H., Mutterlose., 2005. Stable organic carbon isotope stratigraphy across Oceanic Anoxic Event 2 of Demerara Rise, western tropical Atlantic. Geochemistry, Geophysics, Geosystems, 6(6), 1-9, doi:10.1029/2004GC000850

Evitt, W.R. 1985. Sporopollenin dinoflagellate cysts. Their morphology and interpretation. American Association of Stratigraphic Palynologists Foundation, Dallas. 333 pp.

Fensome, R.A. and Williams, G.L. 2004. The Lentin and Williams Index of Fossil Dinoflagellates 2004 Edition. AASP Contribution Series No. 42. 
Forster, A., S. Schouten, K. Moriya, P. A. Wilson, and J. S. Sinninghe Damsté (2007), Tropical warming and intermittent cooling during the Cenomanian/Turonian oceanic anoxic event 2: Sea surface temperature records from the equatorial Atlantic,Paleoceanography, 22, PA1219, doi:10.1029/2006PA001349.

Friedrich, O., Erbacher, J., Moriya, K., Wilson, P.A. and Kuhnert, H. 2008. Warm saline intermediate waters in the Cretaceous tropical Atlantic Ocean. Nature Geoscience, 1, 453-457.

Hasegawa, T., Crampton, J.S., Schiøler, P., Field, B. Fukushi, C., Kakizaki, Y. 2013. Carbon isotope stratigraphy and depositional oxia through Cenomanian/Turonian boundary sequences (Upper Cretaceous) in New Zealand. Cretaceous Research, 40: 61-80.

Harris A.J, Tocher B.A. 2003. Palaeoenvironmental analysis of late Cretaceous dinoflagellate cyst assemblages using high-resolution sample correlation from the western interior basin, USA. Mar Micropaleontol. 48:127148.

Haq, B.U. 2014. Cretaceous eustacy revisited. Global and Planetary Change, 113, 44-58.

He Cheng-Quan, 1984. Tertiary dinoflagellates and acritacrhs from the coastal region of the Beibu Gulf. Memoirs of Nanjing Institute of Geology and Palaeontology, Academia Sinica, 19: 143-192. [in Chinese with English abstract]

Herngreen, G.F.W. and Chlonova, A.F. 1981. Cretaceous microfloral provinces. Pollen et Spores 23: 441-555.

Herngreen, G.F.W., Kedeves, M., Rovina, L.V. and Smirnova, S.B. 1996. Cretaceous palynofloral provinces: a review. P. 1157-1188, in, Palynology: Principles and Applications, Volume 3. Eds. Jansonius, J. And McGregor, D.C. Salt Lake City. American Association of Stratigraphic Palynologists.

Huber, B.T., Norris, R.D., McLeod, K.D. 2002. Deep-sea paleotemperature record of extreme warmth during the Cretaceous. Geology, 30: 123-126.

Ion, J., Antonescu, E., Melinte, M.C. and Szasz, L. 2004. Integrated biostratigraphy of the Turonian of Romania. Acta Palaeontologica Romaniae, 4: 151-161.

Jain, K.P. and Millepied, P. 1973. Cretaceous microplankton from Senegal Basin, N.W. Africa. 1. Some new genera and species combinations of dinoflagellates. The Palaeobotanist, 20: 22-32.

Jarvis, I., Lignum, J.S., Gröcke, D.R., Jenkyns, H.C., Pearce, M.A., 2011. Black Shale deposition, atmospheric CO2 drawdown, and cooling during the Cenomanian-Turonian Oceanic Anoxic Event. Paleoceanography 26, PA3201. http://dx.doi.org/10.1029/2010PA002081.

Jiang,M.J., 1989. Biostratigraphy and Geochronology of the Eagle Ford Shale, Austin Chalk, and Lower Taylor Marl in Texas Based on Calcareous Nannofossils. Ph.D. dissertation Texas A\&M University (496 p.).

Joo, Y.J., Sageman, B.B., 2014. Cenomanian to Campanian carbon isotope chemostratigraphy from the Western Interior Basin, U.S.A. Journal of Sedimentary Research 84, 529e542. http://dx.doi.org/10.2110/jsr.2014.38

Kauffman, E.G., Pratt, L.M. 1985. A field guide to the stratigraphy, geochemistry, and depositional environments of the Kiowa-Skull Creek, Greenhorn, and Niobrara marine cycles in the Pueblo-Cañon city area, Colorado. In Pratt et al. (Editors) Fine-grained Deposits and Biofacies of the Cretaceous Western Interior Seaway. Society of Economic Paleontologists and Mineralogists, Field trip Guide Book No. 4: FRS/1 - FRS/26.

Kennedy, W.J., Walaszczyk, I. \& Cobban, W.A. 2000. Pueblo, Colorado, USA, Candidate Global Boundary Stratotype Section and Point for the base of the Turonian Stage of the Cretaceous and for the Middle Turonian substage, with a revision of the Inoceramidae (Bivalvia). Acta Geologica Polonica 50, 295-334. 
Kenndey, W.J., Walaszczyk, I., Cobban, W.A., Dodsworth, P., Elder, W.P., Gale, A.S., Scott, G.R., Hancock, J.M., Voigt, S., Kirkland, J.I. 2005. The Global Boundary Stratotype Section and Point for the base of the Turonian Stage of the Cretaceous: Pueblo, Colorado, U.S.A. Episodes 28: 93-104.

Kennedy, W.J., Wright, C.W. and Hancock, J.M. 1987. Basal Turonian ammonites from West Texas. Palaeontology, 30: 27-74. Kenndey, W.J., Walaszczyk, I., Cobban, W.A., Dodsworth, P., Elder, W.P., Gale, A.S., Scott, G.R., Hancock, J.M., Voigt, S., Kirkland, J.I. 2005. The Global Boundary Stratotype Section and Point for the base of the Turonian Stage of the Cretaceous: Pueblo, Colorado, U.S.A. Episodes 28: 93-104.

Krauspenhar P.M., Carvalho, M.A., Fauth, G., Lana, C.C. 2014. Albian Palynostratigraphy of ODP Leg 207 (Holes 1257A, 1258C and 1260B), Demerara Rise, Equatorial Atlantic. Revue de micropaléontologie, 57: 1-15.

Lentin, J.K. and Williams, G.L. 1980. Dinoflagellate provincialism. AASP Contribution Series No. 7, 46pp.

Lowery, C.M., Corbett, M.J., Leckie, M., Watkins, D., Romero, A.M., Pramudito, A., 2014. Foraminiferal and nannofossil paleoecology and paleoceanography of the Cenomanian-Turonian Eagle Ford Shale of southern Texas. Palaeogeography, Palaeoclimatology, Palaeoecology 413, 49-65.

Lundquist, J.J., 2000. Foraminiferal Biostratigraphic and Paleoceanographic Analysis of the Eagle Ford, Austin, and Lower Taylor Groups (Middle Cenomanian through Lower Campanian) of Central Texas. University of Texas at Austin (Ph.D. dissertation, 545 p.).

Makled, W.A, Mostafa, T.F. \& Maky, A.B.F. 2014. Mechanism of late Campanian - early Maastrichtian oil shale deposition and its sequence stratigraphy implications inferred from the palynological and geochemical analysis. Egyptian Journal of Petroleum, 23: 427-444.

Marshall, K.L., Batten, D.J. 1988. Dinoflagellate cyst associations in Cenomanian-Turonian 'Black Shale' sequences of northern Europe. Review of Palaeobotany and Palynology, 54: 85-103.

Mertens, K.N., Verhoeven, K., Verleye, T., Louwye, S., Amorim, A., Ribeiro, S., Deaf, A.S., Harding, I.C., De Schepper, S., Gonz_alez, C., Kodrans-Nsiah, M., De Vernal, A., Henry, M., Radi, T., Dybkjaer, K., Poulsen, N.E., Feist-Burkhardt, S., Chitolie, J., Heilmann-Clausen, C., Londeix, L., Turon, J.-L., Marret, F., Matthiessen, J., McCarthy, F.M.G., Prasad, V., Pospelova, V., Kyffin Hughes, J.E., Riding, J.B., Rochon, A., Sangiorgi, F., Welters, N., Sinclair, N., Thun, C., Soliman, A., Van Nieuwenhove, N., Vink, A., Young, M., 2009. Determining the absolute abundance of dinoflagellate cysts in recent marine sediments: The Lycopodium marker-grain method put to the test,. Review of Palaeobotany and Palynology 157, 238-252. http://dx.doi.org/10.1016/j.revpalbo.2009.05.004.

Meyers, S.R., 2007. Production and preservation of organic matter: The significance of iron. Paleoceanography 22, PA4211. http://dx.doi.org/10.1029/2006PA001332

Minisini, D., Eldrett, J.S., Bergman, S.C., Forkner, R., Ozkan, A. in review. Chronostratigraphic Framework and Depositional Environments in the Organic-Rich Eagle Ford Group, Texas, USA. Sedimentology.

Mohr, B.A.R., Wähnert, V., Lazarus, D. 2002. Mid-Cretaceous paleobotany and palynology of the central Kerguelen Plateau, southern Indian Ocean (ODP Leg 183, Site 1138). In Frey, F.A., Coffin, M.F., Wallace, P.J. \& Quilty, P.G. (Eds.) Proc. ODP, Sci. Results, 183: 1-39.

Morgan, R. 1978. Albian to Senonian palynology of Site 364, Angola basin. Initial Reports of the Deep Sea Drilling Project, 40: 915-951. 
Nichols, D.J. and Sweet, A.R. 1993. Biostratigraphy of nonmarine palynofloras in a north-south transect of the Western Interior basin. In Caldwell, W.G.E. and Kauffman, E.G. (editors) Evolution of the Western Interior Basin. Geological Association of Canada Special Paper 39: 539-584.

Pearce, M.A., Jarvis, I., Tocher, B.A. 2009. The Cenomanian-Turonian boundary event, OAE2 and palaeoenvironmental change in epicontinental seas: new insights from the dinocyst and geochemical records. Palaeogeography, Palaeoclimatology, Palaeocology 280: 207-234

Pessagno, E.A. 1969. Upper Cretaeous stratigraphy of the western Gulf Coast area of Mexico, Texas and Arkansas. Geological Society of America memoir 111, 139pp.

Peyrot, D., Barroso-Barcenilla, F., Barrón, E., Comas-Rengifo, M.J. 2011. Palaeoenvironmental analysis of Cenomanian-Turonian dinocyst assemblages from the Castilian Platform (Northern-Central Spain). Cretaceous Research 32: 504-526.

Peyrot, D., Barroso-Barcenilla, F., Feist-Burkhardt, S. 2012. Palaeoenvironmental controls on late Cenomanianearly Turonian dinoflagellate cyst assemblages from Condemios (Central Spain). Review of Palaeobotany and Palynology 180: 25-40.

Pratt, L.M. and Threlkeld, C.N. 1984. Stratigraphic Significance of 13C/12C Ratios in Mid-Cretaceous Rocks of the Western Interior, U.S.A. The Mesozoic of Middle North America. Eds. D.F. Stott and D.J. Glass. Canadian Society of Petroleum Geologists 9 (1984): 305-312.

Pratt, L. 1985. Isotopic studies of organic matter and carbonate in rocks of the Greenhorn marine cycle. In Pratt et al. (Editors) Fine-grained Deposits and Biofacies of the Cretaceous Western Interior Seaway. Society of Economic Paleontologists and Mineralogists, Field trip Guide Book No. 4: 38-48.

Prauss, M.L., 2012a. The Cenomanian/Turonian Boundary Event (CTBE) at Tarfaya, Morocco: palaeoecological aspects as reflected by marine palynology. Cretaceous Research 34, p. 233-256. http://dx.doi.org/10.1016/j.cretres.2011.11.004.

Prauss, M.L., 2012b. The Cenomanian/Turonian Boundary Event (CTBE) at Tarfaya, Morocco, northwest Africa: Eccentricity controlled water column stratification as major factor for total organic carbon (TOC) accumulation: Evidence from marine palynology. Cretaceous Research, 37 p.246-260.

Prauss, M.L., 2012c. Potential freshwater dinocysts from marine upper Cenomanian to upper Coniacian strata of Tarfaya, northwest Africa: Three new species of Bosedinia. Cretaceous Research, 37, p.285-290.

Reichart, G.-J., Brinkhuis, H., 2003. Late Quaternary Protoperidinium cysts as indicators of paleoproductivity in the northern Arabian Sea. Marine Micropaleontology v. 49 (4), p. 303- 370.

Sageman, B.B., Meyers, S.R., Arthur, M.A. 2006. Orbital timescale for the Cenomanian-Turonian boundary stratotype and OAE II, central Colorado, USA. Geology, 34: 125-128.

B. Sames, B., Wagreich, M.,Wendler, J.E., Haq, B.U., Conrad, C.P., Melinte-Dobrinescu, M.C., Hu, X., Wendler, I., Wolfgring, E., Yilmaz, I.Ö, Zorina, S.O. 2016. Review: Short-term sea-level changes in a greenhouse world - A view from the Cretaceous, Palaeogeography, Palaeoclimatology, Palaeoecology, Volume 441, Part 3, 393-411, https://doi.org/10.1016/j.palaeo.2015.10.045.

Schrank, E. 1988. Effects of chemical processing on the preservation of Peridinioid Dinoflagellates: A case from the Late Cretaceous of NE Africa. Review of Palaeobotany and Palynology, 56: 123-140.

Shipboard Scientific Party, 2000. Site 1138. In Coffin, M.F., Frey, F.A., Wallace, P.J., et al., Proc. ODP, Init. 
Shipboard Scientific Party, 2004a. Site 1260. In Erbacher, J., Mosher, D.C., Malone, M.J., et al., Proc. ODP, Init. Repts., 207: College Station, TX (Ocean Drilling Program), 1-113. doi:10.2973/odp.proc.ir.207.107.2004 Shipboard Scientific Party, 2004b. Site 1261. In Erbacher, J., Mosher, D.C., Malone, M.J., et al., Proc. ODP, Init. Repts., 207: College Station, TX (Ocean Drilling Program), 1-103. doi:10.2973/odp.proc.ir.207.108.2004

Schiøler, P., Crampton, J.S. 2014. Dinoflagellate biostratigraphy of the Arowhanan Stage (upper Cenomanianlower Turonian) in the East Coast Basin, New Zealand. Cretaceous Research, 48: 205-224.

Sluijs, A., Pross, J. and Brinkhuis, H. 2005. From greenhouse to icehouse; organic-walled dinoflagellate cysts as paleoenvironmental indicators in the Paleogene, Earth Science Review, v. 68, 281-315.

Stenzel, H.B. 1953. The geology of Henrys Chapel quadrangle, northeastern Cherokee County, Texas. Texas University Bureau Economic Geology Publication 5305, 119p.

Traverse, A. 2007. Paleopalynology. (2nd Edition). Springer. ISBN 978-1-4020-6684-9.

Tribovillard, N., Algeo, T., Lyons, T.W., and Riboulleau, A., 2006, Trace metals as paleoredox and paleoproductivity proxies: An update. Chemical Geology, v. 232, p. 12-32, doi:10.1016/j.chemgeo.2006.02.012.

van Helmond, N. A. G. M., Sluijs, A., Papadomanolaki, N. M., Plint, A. G., Gröcke, D. R., Pearce, M. A., Eldrett, J. S., Trabucho-Alexandre, J., Walaszczyk, I., van de Schootbrugge, B., and Brinkhuis, H. 2016. Equatorward phytoplankton migration during a cold spell within the Late Cretaceous super-greenhouse, Biogeosciences, 13, 2859-2872, doi:10.5194/bg-13-2859-2016.

Voigt, S., Erbacher, J., Mutterlose, J., Weiss, W., Westerhold, T., Wiese, F., Wilmsen, M., and Wonik, T. 2008. The Cenomanian-Turonian of the Wunstorf section (north Germany): Global stratigraphic reference section and new orbital time scale for oceanic anoxic event 2, Newsl. Stratigr., 43, 65-89, doi:10.1127/00780421/2008/0043-0065.

Young, K. "Guidebook to the Geology of Travis County." University of Texas at Austin: The Student Geological Society, 1977. p. 171.

Zonneveld, K. A. F., Marret, F., Versteegh, G. J. M., Bogus, K., Bonnet, S., Bouimetarhan, I., Crouch, E., de Vernal, A., Elshanawany, R., Edwards, L., Esper, O., Forke, S., Grøsfjeld, K., Henry, M., Holzwarth, U., Kielt, J.-F., Kim, S.- Y., Ladouceur, S., Ledu, D., Chen, L., Limoges, A., Londeix, L., Lu, S.-H., Mahmoud, M. S., Marino, G., Matsouka, K., Matthiessen, J., Mildenhal, D. C., Mudie, P., Neil, H. L., Pospelova, V., Qi, Y., Radi, T., Richerol, T., Rochon, A., Sangiorgi, F., Solignac, S., Turon, J.-L., Verleye, T., Wang, Y., Wang, Z., and Young, M. 2013. Atlas of modern dinoflagellate cyst distribution based on 2405 data points, Rev. Palaeobot. Palyno., 191, 1- 197, doi:10.1016/j.revpalbo.2012.08.003. 